\title{
Climate and land use change impacts on global terrestrial ecosystems and river flows in the HadGEM2-ES Earth system model using the representative concentration pathways
}

\author{
R. A. Betts ${ }^{1,2}$, N. Golding ${ }^{1}$, P. Gonzalez ${ }^{3}$, J. Gornall ${ }^{1}$, R. Kahana ${ }^{1}$, G. Kay ${ }^{1}$, L. Mitchell ${ }^{1}$, and A. Wiltshire ${ }^{1}$ \\ ${ }^{1}$ Met Office Hadley Centre, FitzRoy Road, Exeter, EX1 3PB, UK \\ ${ }^{2}$ College of Life and Environmental Sciences, University of Exeter, Hatherley Laboratories, Prince of Wales Road, Exeter, \\ EX4 4PS, UK \\ ${ }^{3}$ Natural Resource Stewardship and Science, US National Park Service, Washington, DC 20005-5905, USA
}

Correspondence to: R. A. Betts (richard.betts@metoffice.gov.uk)

Received: 31 January 2013 - Published in Biogeosciences Discuss.: 2 April 2013

Revised: 9 August 2013 - Accepted: 20 August 2013 - Published: 3 March 2015

\begin{abstract}
A new generation of an Earth system model now includes a number of land-surface processes directly relevant to analyzing potential impacts of climate change. This model, HadGEM2-ES, allows us to assess the impacts of climate change, multiple interactions, and feedbacks as the model is run. This paper discusses the results of centuryscale HadGEM2-ES simulations from an impacts perspective - specifically, terrestrial ecosystems and water resources - for four different scenarios following the representative concentration pathways (RCPs), used in the Fifth Assessment Report of the Intergovernmental Panel on Climate Change (IPCC, 2013, 2014). Over the 21st century, simulated changes in global and continental-scale terrestrial ecosystems due to climate change appear to be very similar in all 4 RCPs, even though the level of global warming by the end of the 21 st century ranges from $2{ }^{\circ} \mathrm{C}$ in the lowest scenario to $5.5^{\circ}$ in the highest. A warming climate generally favours broadleaf trees over needleleaf, needleleaf trees over shrubs, and shrubs over herbaceous vegetation, resulting in a poleward shift of temperate and boreal forests and woody tundra in all scenarios. Although climate related changes are slightly larger in scenarios of greater warming, the largest differences between scenarios arise at regional scales as a consequence of different patterns of anthropogenic land cover change. In the model, the scenario with the lowest global warming results in the most extensive decline in tropical forest cover due to a large expansion of agriculture. Under all four RCPs, fire potential could increase across extensive land
\end{abstract}

areas, particularly tropical and sub-tropical latitudes. River outflows are simulated to increase with higher levels of $\mathrm{CO}_{2}$ and global warming in all projections, with outflow increasing with mean temperature at the end of the 21 st century at the global scale and in North America, Asia, and Africa. In South America, Europe, and Australia, the relationship with climate warming and $\mathrm{CO}_{2}$ rise is less clear, probably as a result of land cover change exerting a dominant effect in those regions.

\section{Introduction}

Previous projections of potential future vegetation indicate substantial susceptibility of ecosystems to biome shifts (Fig. 1, Table 1). Five dynamic global vegetation models (DGVMs) and one equilibrium climate model project changes of the potential biome on 5-30\% of global land from $\sim 1990$ to 2100 for a range of the CMIP3 General Circulation Model (GCM) runs of the IPCC SRES emissions scenarios (Scholze et al., 2006; Alo and Wang, 2008; Sitch et al., 2008; Gonzalez et al., 2010; Bergengren et al., 2011). This is a similar order of magnitude to the $25 \%$ change in global land cover from "natural" to "cultivated" over the period 1700-2000 (Ellis et al., 2010). Time lags between greenhouse gas emissions or removals, changes in climate, and vegetation response commit ecosystems to change long before responses become manifest (Rosenzweig et al., 2008; 
Table 1. Studies of projected biome changes. B1, A1B, A2 and A1FI refer to emissions scenarios from the IPCC Special Report on Emissions Scenarios (SRES; Nakićenović et al., 2000).

\begin{tabular}{|c|c|c|c|c|c|c|c|c|c|}
\hline Area & $\begin{array}{r}\Delta \text { Temperature, } \\
\left({ }^{\circ} \mathrm{C}\right)\end{array}$ & $\begin{array}{r}\text { Emissions } \\
\text { scenario }\end{array}$ & $\begin{array}{r}\text { Number } \\
\text { of GCMs }\end{array}$ & $\begin{array}{r}\text { Vegetation } \\
\text { model }\end{array}$ & $\begin{array}{r}\text { Number } \\
\text { of biomes }\end{array}$ & $\begin{array}{r}\text { Spatial resolution } \\
(\mathrm{km})\end{array}$ & $\begin{array}{r}\text { Biome change, } \\
\text { fraction of area } \\
(\%)\end{array}$ & Criterion & Reference \\
\hline \multicolumn{10}{|c|}{ Dynamic global vegetation models (DGVMs) } \\
\hline World & 1.5 & $+<2^{\circ} \mathrm{C}$ & 16 & LPJ & 2 & $\sim 150$ & $\sim 5$ & $P>0.80$ & Scholze et al. (2006) \\
\hline World & 2.4 & B1 & 3 & MC1 & 13 & 50 & 10 & confidence $>0.8$ & Gonzalez et al. (2010) \\
\hline World & 2.5 & $+2-3^{\circ} \mathrm{C}$ & 16 & LPJ & 2 & $\sim 150$ & $\sim 5$ & $P>0.80$ & Scholze et al. (2006) \\
\hline World & 3.4 & A1B & 3 & $\mathrm{MC1}$ & 13 & 50 & 13 & confidence $>0.8$ & Gonzalez et al. (2010) \\
\hline World & 3.5 & $+>3^{\circ} \mathrm{C}$ & 16 & LPJ & 2 & $\sim 150$ & $\sim 5$ & $P>0.80$ & Scholze et al. (2006) \\
\hline World & 4 & A2 & 3 & MC1 & 13 & 50 & 16 & confidence $>0.8$ & Gonzalez et al. (2010) \\
\hline World & $3.1-4.7$ & $\begin{array}{l}\text { historical climate } \\
\text { and B1, A1B, A2 }\end{array}$ & 3 & $\mathrm{MC} 1$ & 13 & 50 & 12 & confidence $>0.8$ & Gonzalez et al. (2010) \\
\hline World & $\sim 3.5-5.5$ & A1B & 8 & CLM & 5 & $\sim 280$ & $\sim 10-30$ & range of GCMs & Alo and Wang (2008) \\
\hline World & 4.6 & A1FI & 1 & HyLand & 2 & $\sim 250 \times 375$ & $\sim 10$ & $\mid$ change $\mid>50 \%$ of area & Sitch et al. (2008) \\
\hline World & 4.6 & A1FI & 1 & LPJ & 2 & $\sim 250 \times 375$ & $\sim 20$ & $\mid$ change $\mid>50 \%$ of area & Sitch et al. (2008) \\
\hline World & 4.6 & A1FI & 1 & ORCHIDEE & 2 & $\sim 250 \times 375$ & $\sim 10$ & $\mid$ change $\mid>50 \%$ of area & Sitch et al. (2008) \\
\hline World & 4.6 & A1FI & 1 & TRIFFID & 2 & $\sim 250 \times 375$ & $\sim 15$ & $\mid$ change $\mid>50 \%$ of area & Sitch et al. (2008) \\
\hline Africa & Un-reported & A1B & 1 & aDGVM & 5 & $\sim 30$ & $\sim 26$ & change in one GCM & $\begin{array}{l}\text { Scheiter and } \\
\text { Higgins (2009) }\end{array}$ \\
\hline Amazon & 2 & A2 & 1 & HadCM3LC & 2 & $\sim 250 \times 375$ & $\sim 30$ & change in one GCM & Jones et al. (2009) \\
\hline Europe & $2.9-4.9$ & A2 & 2 & LPJ-GUESS & 13 & $\sim 12 \times 18$ & $\sim 30-40$ & change in one GCM & Hickler et al. (2012) \\
\hline Europe & $2.9-4.9$ & A2 & 2 & LPJ-GUESS & 13 & $\sim 12 \times 18$ & $\sim 30-40$ & change in one GCM & Hickler et al. (2012) \\
\hline Siberia & 2 & $+2.6^{\circ} \mathrm{C}$ after $130 \mathrm{yr}$ & none & FAREAST & 2 & 372 sites & $\sim 5$ & |change $\mid>50 \%$ of area & Shuman et al. (2011) \\
\hline \multicolumn{10}{|c|}{ Equilibrium models } \\
\hline World & $2-4$ & A1B & 10 & EVE & 5 & $\sim 100$ & 37 & average of GCMs & Bergengren et al. (2011) \\
\hline Tropical forests & 2 & $+2^{\circ} \mathrm{C}$ & 16 & MWCD & 2 & $\sim 100$ & $<5$ & $P>0.80$ & Zelazowski et al. (2011) \\
\hline Tropical forests & 4 & $+4^{\circ} \mathrm{C}$ & 16 & MWCD & 2 & $\sim 100$ & $\sim 5$ & $P>0.80$ & Zelazowski et al. (2011) \\
\hline South America & Un-reported & A2 & 14 & CPTEC-PVM2 & 13 & $\sim 170$ & $\sim 5-40$ & confidence $>0.75$ & Lapola et al. (2009) \\
\hline West Africa & Un-reported & $\mathrm{A} 2$ & 17 & GAM & 5 & $\sim 10$ & $\sim 50$ & weighted average of GCMs & Heubes et al. (2011) \\
\hline
\end{tabular}

Jones et al., 2009). Tropical forest, savanna, and treeless areas may exist as alternative stable states with tipping points related to precipitation (Hirota et al., 2011). The variable skill of DGVMs to accurately simulate terrestrial vegetation, different biome classifications, and varying $\mathrm{CO}_{2}$ fertilisation methods suggest caution in interpreting DGVM results.

Projections generally agree on extensive poleward shifts of vegetation and degradation of tropical biomes, although the exact spatial distributions of various biomes differ substantially due to differences in GCMs, emissions scenarios, and vegetation models (Fig. 1). Regional vegetation modelling results (Table 1; Jones et al., 2009; Scheiter and Higgins, 2009; Shuman et al., 2011; Hickler et al., 2012) are consistent with the global projections. Tundra, alpine, and boreal conifer biomes show the highest modelled vulnerability to biome shifts, due to high exposure and high sensitivity to warm temperatures. Such changes are becoming evident in Earth observation records, with a "greening" trend being seen in general across northern latitudes but with important regional differences (Goetz et al., 2007). Temperate mixed forest shows high modelled vulnerability due to projected loss of coniferous species and thus conversion to temperate broadleaf forest. Tropical evergreen broadleaf forest generally shows low modelled vulnerability to biome shifts, with the exception of the Amazon. Some evidence indicates a higher resilience of rainforests from high-temperature tolerances and mitigation of water stress by increases in equatorial precipitation (Malhi et al., 2008) and the wide latitudinal ranges of woody plant species (Weiser et al., 2007). Other evidence suggests higher vulnerability of tropical rainforests (Colwell et al., 2008; Bertrand et al., 2011).

Previous studies have used climate projections driven by the SRES scenarios, sometimes focussing on specific levels of global warming. Although some assessments of global hydrological impacts have used runoff projections directly from GCMs (e.g. Nohara et al., 2006), a more usual methodology for impact assessments is to use meteorological outputs from GCMs to provide climate change anomalies, which are imposed on a present-day observational climatology to provide climate driving data for impacts models. Although GCMs simulate the present-day patterns of global climate with some success, they nevertheless often feature systematic biases in some regional climates which can lead to unrealistic simulations of ecosystems and hydrology in some regions. Use of an observational climatology plus projected climate anomalies allows for more realistic patterns of impacts quantities at the present-day. It can also potentially address unrealistic constraints on projected changes, if, for example, dry biases in precipitation mean that further reductions are limited even if the atmospheric circulation changes suggest that they should occur. However, use of climate anomalies may violate conservation of physical quantities such as water, and also lead to inconsistencies between aspects of the climate system simulated in impact models separately from climate models.

While the GCMs used for climate impact assessment have generally been atmosphere-ocean GCMs, a parallel line of model development has involved the implementation of dynamic vegetation and biogeochemical feedbacks in GCMs 

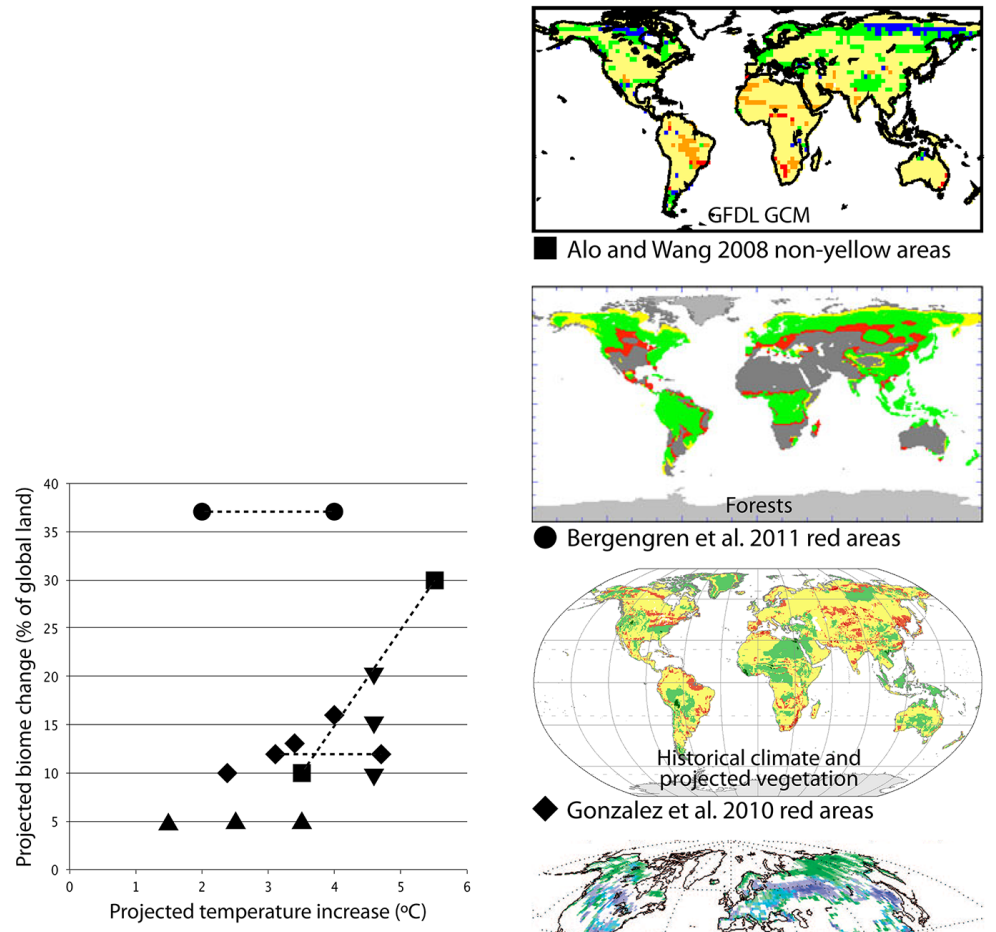

Alo and Wang 2008 non-yellow areas

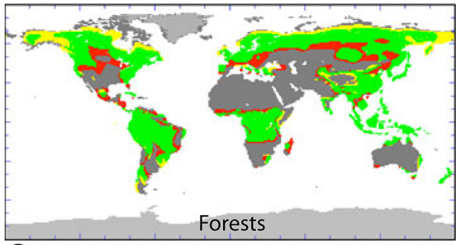

Bergengren et al. 2011 red areas

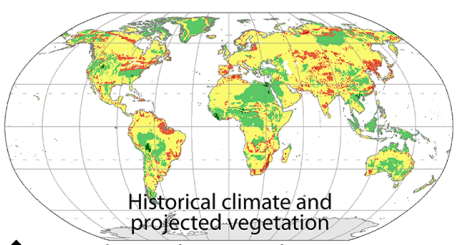

Gonzalez et al. 2010 red areas

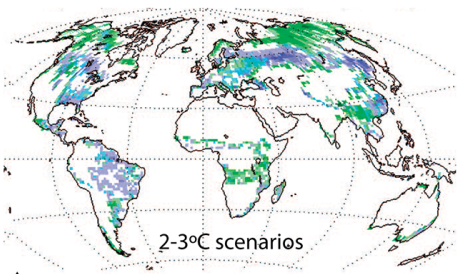

A Scholze et al. 2006 dark areas

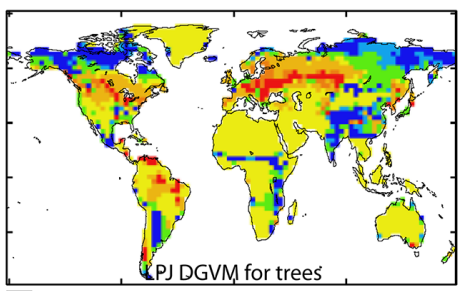

Sitch et al. 2008 red and blue areas

Figure 1. Projected changes in terrestrial ecosystems in previous studies. Right-hand panels show global maps of projected changes. Lefthand panel shows percentage of global land projected to undergo biome change in these studies, for different levels of increase in global mean temperature.

to produce Earth system models (ESMs). Feedbacks from global vegetation change, for example, can have important impacts on projections of future climate change (e.g. Levis et al., 2000; Matthews et al., 2004). The Earth system configuration of the 2nd Hadley Centre Global Environmental Model (HadGEM2-ES) has been designed for the specific purpose of simulating and understanding the centennial-scale evolution of climate including ecosystem and hydrological processes in a fully consistent manner. It is the first Met Office Hadley Centre (MOHC) Earth system model to run without the need for flux corrections. The previous MOHC climate model (HadGEM1) (Johns et al., 2006) did not include biogeochemical feedbacks, and the previous carbon cycle model in the Hadley Centre (HadCM3LC) (Cox et al., 2000) used artificial correction terms to keep the model state from drifting.

The inclusion of Earth system components in a climate model has a two-fold benefit. It allows an online consistent calculation of the impacts of climate change on atmospheric composition or ecosystems for example, which can be scientifically valuable in its own right (e.g. Jones et al., 2009). The second benefit is that it allows the incorporation of biogeochemical feedbacks which can either be negative: dampening the sensitivity of the climate to external forcing; or positive: amplifying the sensitivity (Levis et al., 2000; Matthews et al., 2004). Given the presence of these feedbacks, impacts of climate change on ecosystems and hydrology simulated within ESMs will be fully consistent with the overlying cli- 
mate, with any changes in surface energy and moisture fluxes associated with changes in vegetation and soil moisture continuing to conserve the surface energy balance and hydrological cycle. However, this may not necessarily be the case for ecosystem and hydrological impact studies carried out with models separate from the ESMs and using its meteorological outputs as inputs to their own separate calculations. Since HadGEM2-ES and other ESMs have been used to provide data for the 5th Coupled Model Intercomparison Project (CMIP5), they are likely to be widely used for driving models of ecosystem and hydrological impacts, and previous experience suggests that these studies will give a range of different results. Ecosystem and hydrological changes which are widely different from those projected by the ESMs themselves may therefore be less physically plausible if they are associated with significant departures from conservation of energy and moisture.

Integration of ecosystem and hydrological impacts within the Earth system model also allows other drivers of change to be included, such as anthropogenic land cover change. As well as affecting ecosystems directly, land cover changes can also affect climate and hydrology through changes in surface energy and moisture fluxes. Inclusion of land cover change as a driver of ecosystem change within the Earth system model therefore allows its impacts on climate, ecosystem, and hydrological changes to be simulated consistently. This is particularly important when using the Earth system model to examine the impacts of different emissions scenarios in which land use change contributes a key component of the emissions.

The current generation of dynamic global vegetation models generally focus on plant physiological processes as drivers of vegetation dynamics in response to climate change, and this is true of the vegetation model within HadGEM2ES. However, vegetation disturbance also plays a critical role in affecting vegetation cover, and changes in disturbance regime may be a key aspect of climate change impacts on ecosystems. Fire disturbance may be particularly important (Li et al., 2000), especially when human land use is potentially providing sources of ignition (Kloster et al., 2012). In addition to land use being a direct impact on ecosystems, interactions between climate change and land use through fire may therefore also play a critical role.

This paper has three aims:

1. To present the impacts of climate change on terrestrial ecosystems and hydrology simulated directly by HadGEM2-ES, for comparison against previous studies and to provide a reference against which other impacts studies using HadGEM2-ES meteorological outputs can be compared in order to assess potential plausibility in terms of consistency with the overlying climate.

2. To assess the relative importance of climate change and anthropogenic land cover change on vegetation distri- bution in HadGEM2-ES, under different emissions scenarios including different scenarios of land use.

3. To assess the potential for additional impacts not included in the current model which may arise from an interaction between climate change and land use via wildfire.

Three specific questions to be addressed are

1. How do the projected changes in global ecosystems and hydrology compare with previous work?

2. How important is anthropogenic land cover change in comparison with anthropogenic climate change as a driver of global vegetation change in this model in different RCP scenarios?

3. How does a meteorologically defined forest fire danger change as a result of the projected climate changes?

\section{Methods}

\subsection{The HadGEM2-ES Earth system model}

HadGEM2-ES (Collins et al., 2011) is an Earth system model based on the HadGEM2 atmosphere-ocean general circulation model (Martin et al., 2011), with additional representation of global-scale processes of biology and chemistry. The atmospheric resolution is $\mathrm{N} 96\left(1.875^{\circ} \times 1.25^{\circ}\right)$ with $38 \mathrm{lev}-$ els, and the ocean resolution is $1^{\circ}$ (increasing to $1 / 3^{\circ}$ at the equator) with 40 levels. HadGEM2-ES has been used to simulate future climate change (Jones et al., 2010; Caeser et al., 2013) following a number of scenarios under the representative concentration pathways (Moss et al., 2010).

Land-surface processes including plant physiology and the surface energy and moisture budgets are simulated with the 2nd version of the Met Office Surface Exchange Scheme (MOSES II; Cox et al., 1999; Essery et al., 2003). Some improvements have been made compared to previously published versions of MOSES II in order to improve the simulation of global carbon cycle processes (Collins et al., 2010), including improved representations of deep soil moisture (Clark and Gedney, 2008), wetlands (Gedney et al., 2004), and penetration of light into vegetation canopies (Mercado et al., 2007). MOSES II also includes large-scale vegetation dynamics simulated by TRIFFID (Cox, 2001) - the global patterns of vegetation are simulated within the Earth system model, with vegetation represented by 5 plant functional types (PFTs): broadleaf tree, needleleaf tree, C3 grass, C4 grass, and shrub. These PFTs compete with each other on the basis of competition rules and the net carbon uptake of each PFT simulated within the land-surface scheme closely coupled with the water budget. Natural disturbance is prescribed by a uniform disturbance rate - there is no representation of the effects of climate on disturbance regimes 
such as fire, windthrow, disease, or insect attack, and neither is there any explicit representation of herbivory. The implicit assumption in the model, therefore, is that natural disturbance regimes remain constant over time. This may be a limitation of the model when used in climate change studies, as will be discussed below. Anthropogenic land use is simulated through the imposition of a "disturbed fraction" which designates a specific fraction of the grid box as unavailable to tree and shrub PFTs - all agricultural land including croplands is therefore represented as either $\mathrm{C} 3$ or $\mathrm{C} 4$ grass, depending on which is simulated to grow best under local climate conditions.

In addition to the plant functional types, each grid cell includes a prescribed fraction of lakes, ice, and urban areas that do not vary.

The physical properties of the land surface, such as albedo, aerodynamic roughness, and factors affecting moisture availability for evaporation, are directly affected by the PFT distribution and the simulated leaf area index (LAI) of each PFT and the fractional cover and physical properties of the ice, water and bare soil portions of the grid box; this means that changes in vegetation cover directly influence the climate through the surface energy and moisture budgets.

A key feature of HadGEM2-ES and other Earth system models is that terrestrial ecosystems and hydrology are tightly coupled. Changes in vegetation cover, either in response to climate change or anthropogenic land use, affect surface evaporation and transpiration rates, with consequent implications for soil moisture and surface and sub-surface runoff. The strength of the effect of land-surface conditions on surface moisture fluxes varies from region to region and between models (Koster et al., 2004). Vegetation responses to increasing $\mathrm{CO}_{2}$ concentrations also affect the hydrology through changes in transpiration, with higher $\mathrm{CO}_{2}$ concentrations generally resulting in decreased transpiration and increased runoff (Betts et al., 2007). Total runoff is routed to the oceans using the TRIP global river model (Oki and Sud, 1998), which simulates river flows through a network resolved on a $1^{\circ} \times 1^{\circ}$ grid.

The simulations of terrestrial ecosystem distribution and river flows in HadGEM2-ES are therefore fully consistent with each other and with the overlying climate. Changes in vegetation and hydrology therefore involve the same changes in evaporative fluxes, which is often not the case when these two impacts of climate change are studies separately. Moreover, changes in evaporation and precipitation will be consistent, and conserve water in the global hydrological cycle. Simulations of hydrological impacts of climate change with models separate from GCMs and using climate model anomalies applied to observed climatologies may involve evaporation calculations which are different to those in the driving climate model, and hence may be inconsistent. This may lead to biases in the long-term trend; for example, if a hydrological model simulates a greater fraction of precipitation to be returned to the atmosphere as evaporation with less available for runoff and river flow, this is not available for increasing atmospheric moisture in the climate model, so water is lost from the system. A fully coupled system as used here, and in other modelling systems (e.g. D. M. Lawrence et al., 2012) allows important processes such as the global water cycle to obey physical laws of conservation.

The trade-off with this approach is that biases in the regional climate patterns in the climate model may be reflected in less realistic simulations of ecosystem and hydrological states at the present day. Therefore, the model results used here should still be regarded as somewhat indicative. Nevertheless, they may provide some insight into the implications of climate and land use change for terrestrial ecosystem and hydrological impacts in a fully internally consistent system.

Under present-day forcings of greenhouse gas and aerosol concentrations and anthropogenic land use disturbance, HadGEM2-ES simulates global patterns of vegetation with some success (Collins et al., 2011). The major forest zones of tropical and boreal forests are simulated, with the main exception being the deciduous needleleaf regions of eastern Siberia. Here, the model features shrub cover instead of trees, because the model does not include cold-deciduous phenology in the needleleaf tree PFT, and evergreen needleleaf trees are not viable in the cold conditions of this region. Other boreal forest areas are realistically located but do not extend far enough northwards. Tropical forests of South America and Africa extend too far into savanna regions - this may be because fire disturbance is not included in the model. Forest cover is also too extensive in South East Asia. Some instances of over-extensive forest cover may be due to shortcomings in the imposed disturbed fraction, such that human land use is not accurately represented. Shrublands, grasslands, and deserts are simulated in the appropriate regions of the South America, Africa, and central Asia, although deserts are slightly too extensive at the expense of grass and shrub. In Australia and North America, semi-desert regions are simulated with too little shrub and too much bare soil.

Wildfire is not represented in the model, but may play a key role in future ecosystem change driven by climate or land use change either individually or in combination. To assess whether the HadGEM2-ES projections of ecosystems change may be omitting an important process, we obtain a first-order indication of the implications of the climate changes projected by HadGEM2-ES for wildfire risk. We use daily meteorological outputs from the model to calculate the McArthur Forest Fire Danger Index (FFDI: McArthur, 1973; Noble, 1980) following the method previously used with the HadCM3 model over Amazonia (Golding and Betts, 2008). Daily meteorological data are used to calculate the index, but the analysis presented here will focus on annual means of the FFDI in order to provide a first-order assessment of change. Although the McArthur index has been designed for use in Australian forest ecosystems and hence may not translate perfectly to other global ecosystems, at the broad scale it provides indications of relatively high and low fire dan- 


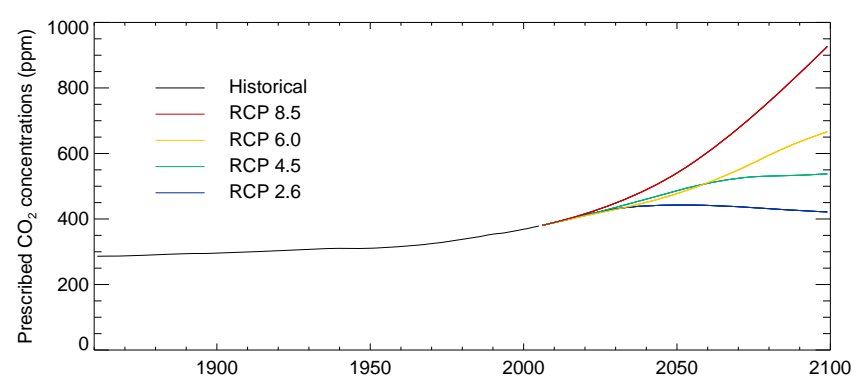

Figure 2. Atmospheric $\mathrm{CO}_{2}$ concentrations in the representative concentration pathways (RCPs) as prescribed as inputs to the HadGEM2-ES simulations in this study.

ger which are generally comparable with other methods. We therefore consider it useful as a first-order indicator of relative changes in global patterns of fire risk.

\subsection{Future projections: scenarios of greenhouse gas and land use changes}

The HadGEM2-ES simulations described here were forced with projected greenhouse gas and aerosol concentrations and land use changes, representing the combined effect of human activities on the climate system. Although HadGEM2-ES includes a global carbon cycle model and hence can be driven by scenarios of $\mathrm{CO}_{2}$ emissions in order to calculate atmospheric $\mathrm{CO}_{2}$ concentrations within the model, the simulations described here were driven by prescribed $\mathrm{CO}_{2}$ concentrations from the representative concentration pathways (RCPs) as part of the 5th Coupled Model Intercomparison Project (CMIP5; Taylor et al., 2012) (Fig. 2). The model also used the RCP scenarios of changes in other anthropogenic greenhouse gases such as methane, nitrous oxide, and halocarbons, and anthropogenic aerosols such as sulfate and black carbon.

Alongside the RCP scenarios of emissions and concentrations of greenhouse gases and aerosols, scenarios of anthropogenic land use have also been developed which are consistent with the emissions scenarios (Hurtt et al., 2010). The land use includes changes in crops and pasture areas, wood harvesting, and land which is recovering from previous human activities ("secondary" land).

The four RCP scenarios share the same historical land use and land cover changes (1860-2005) as reconstructed by the HYDE 3.1 project (Goldewijk, and van Drecht, 2006). The fraction of global crop and pasture areas begins to grow from levels of less then $10 \%$ in the early 1800 s to about $25 \%$ in 1950 (Hurtt et al., 2010). The earliest managed areas are in Europe, North America, East Asia and India followed by South Africa, Australia and South America. Between 1950 and 1960 there is a sharp increase in global crop and pasture areas when a larger proportion of the natural vegetation is being managed in the above regions, and in new areas in Central Asia, Central America, and Africa. Between 1960 and 2005 the managed area fraction in Asia, Africa, and South America is still increasing while it is largely stabilised or slightly decreased in North America, Australia, and Europe where secondary land is left to recover from human activities.

From 2005, the different RCPs are following their own estimates of land use. In the "no-policy" (RCP 8.5) and the "overshoot and decline" (RCP 2.6) pathways, the global managed area continue to increase throughout the 21st century (Fig. 3) mainly in Africa, Central and South America and Australia. In the two other scenarios (RCP 4.5 and RCP 6.0), the global fraction of managed area is decreased with large-scale recovery over northern America, Europe and western Asia (RCP 4.5) and over Central and South America, Africa, and Australia (RCP 6.0) (with some increase in India and East Asia). These four future land use projections were then harmonised and smoothly linked to the historical reconstructions (Hurtt et al., 2010), and are now in use in Earth system models for assessing the impacts of land cover change on climate (e.g. P. J. Lawrence et al., 2012).

\subsection{Implementation of land use changes in HadGEM2-ES}

The projected land use change scenarios accompanying the different RCPs were used to drive changes in land cover in HadGEM2-ES in addition to the model's own simulation of natural vegetation responses to climate change. HadGEM2ES does not explicitly represent crop and pasture; instead, the simulations were forced with a time varying fraction of the managed vegetation, taken as the sum of the projected crop and pasture (but not the wood harvest) data from the Hurtt et al. (2010) data set. In this "human managed" fraction of each grid cell, trees and shrubs are excluded, allowing the model to grow grasses, which represent the managed land (Jones et al., 2011).

The land use scenarios accompanying the RCPs result in very different patterns of change in anthropogenic disturbance over the 21st century (Fig. 3). The scenarios of greatest and least anthropogenic greenhouse gas emissions, RCP8.5 and RCP2.6 respectively, are both accompanied by scenarios of increasing ecosystem disturbance. RCP8.5 is accompanied by expansion of croplands for food, while RCP2.6 uses major areas of land for bioenergy crops as part of the climate change mitigation strategy in order to avoid global warming exceeding $2{ }^{\circ} \mathrm{C}$ relative to pre-industrial. RCP4.5 is accompanied by a global reduction in agricultural land by 2100 compared to the beginning of the 21 st century, and RCP6.0 sees similar reductions in South America, Africa, and western Asia, but increased disturbance in South and South East Asia and little change in Europe and North America. 

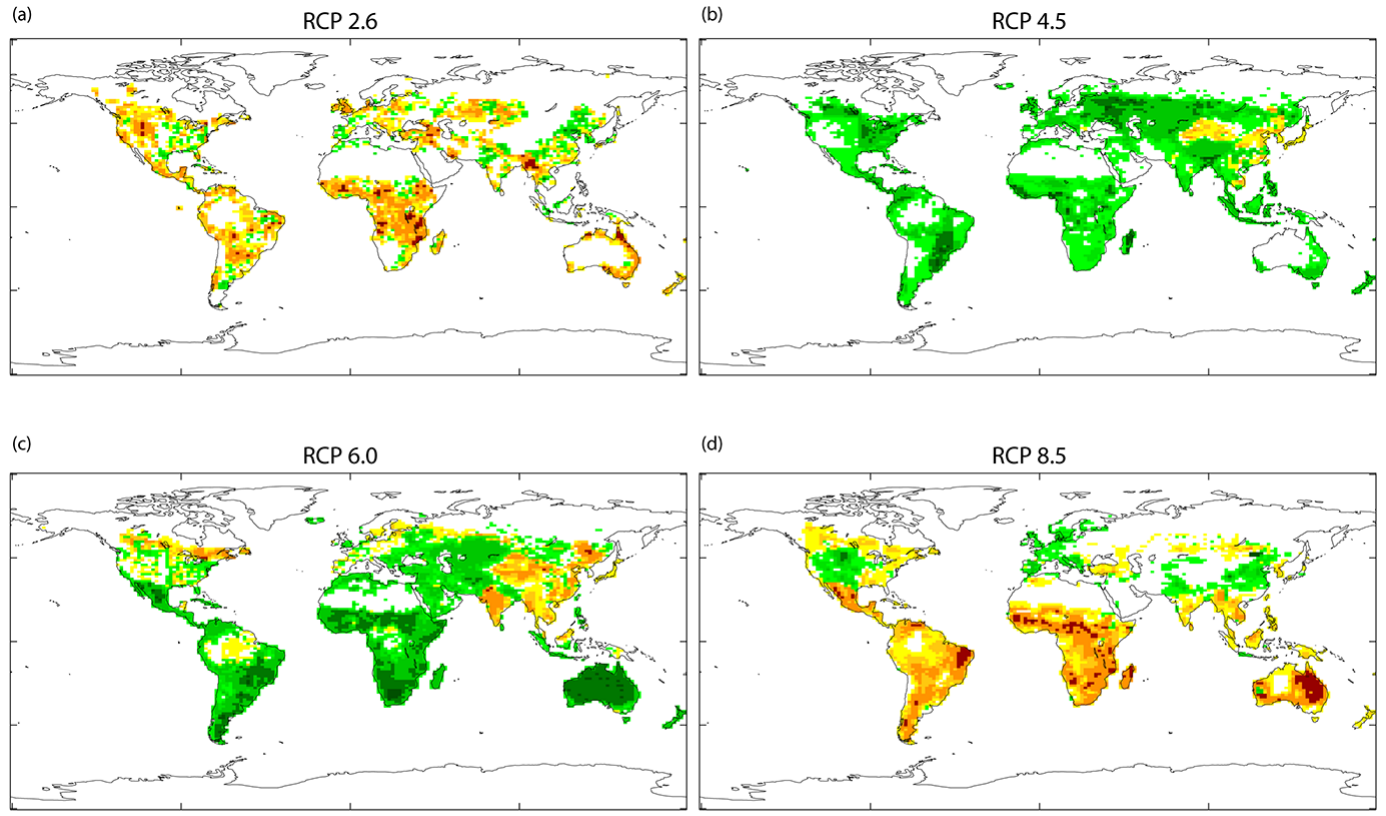

(d) RCP 8.5

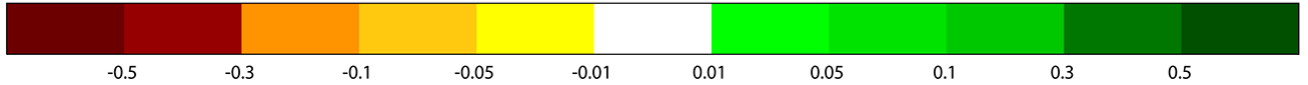

Figure 3. Changes in fraction of land cover disturbed by anthropogenic land use from 2005 to 2100 accompanying (a) RCP2.6, (b) RCP4.5, (c) RCP6.0, (d) RCP8.5, as implemented in HadGEM2-ES following the harmonised land use scenarios of Hurtt et al. (2010).

\section{Results}

\subsection{Climate change}

Global mean temperature increases under all RCPs over the 21st century (Fig. 4a), although in HadGEM2-ES, RCP2.6 gives a peak warming of $2{ }^{\circ} \mathrm{C}$ relative to pre-industrial in the middle of the century and then a slight gradual decline thereafter. RCP 4.5 stabilises at approximately $3{ }^{\circ} \mathrm{C}$ from the 2070 2099 onwards, while RCP6.0 continues warming to approximately $3.5^{\circ} \mathrm{C}$ by the century and RCP8.5 reaches approximately $5.5^{\circ} \mathrm{C}$. The global mean temperature rises of the different RCPs are largely indistinguishable from one another until the 2030s, especially when natural internal variability is taken into account. RCP2.6 and RCP8.5 begin to diverge noticeably from the other two RCPs in the middle of the century, and RCP4.5 and RCP6.0 remain similar to each other in terms of global mean temperature until the 2070-2099.

Global mean precipitation shows a similar response (Fig. 4b), increasing by approximately $2 \%$ by 2100 under RCP 2.6 and nearly $6 \%$ by 2100 under RCP 8.5 . Natural internal variability is larger for precipitation than temperature, and consequently the differences between the RCPs emerge later for precipitation.

Warming is projected across all regions of the globe by the end of the century for all RCPs (Caeser et al., 2013), with greater warming over land and in the Arctic in common with other climate projections (see, for example, Meehl et al., 2007). The geographical patterns of precipitation change are more complex, with some land regions projected to experience increased annual mean precipitation while others are projected to see a decrease (Fig. 5). Broadly the patterns of precipitation change projected by HadGEM2-ES are consistent with the average changes of models assessed in the IPCC 4th Assessment Report (Meehl et al., 2007) although it should be noted that the level of agreement between models varies considerably from region to region, even for the sign of the precipitation change (Christensen et al., 2007). This paper focuses on the climate changes projected specifically by HadGEM2-ES, which may differ from other models in some regions.

\subsection{Changes in terrestrial ecosystems}

In the boreal and temperate regions, HadGEM2-ES simulates shifting patterns of broadleaf tree, needleleaf tree and shrub under all 4 RCPs, with a general poleward shift of all three of these PFTs (Figs. 6, 7, 8). Fractional cover of needleleaf tree increases by approximately $50 \%$ in a region approximately two grid boxes wide along the northern edge of the boreal forests, while decreasing along the southern edge of the present-day needleleaf tree zone. Along the northern edge, shrub cover decreases by $10-30 \%$ as it is outcompeted by needleleaf tree, but increases by $10 \%$ or more from about 

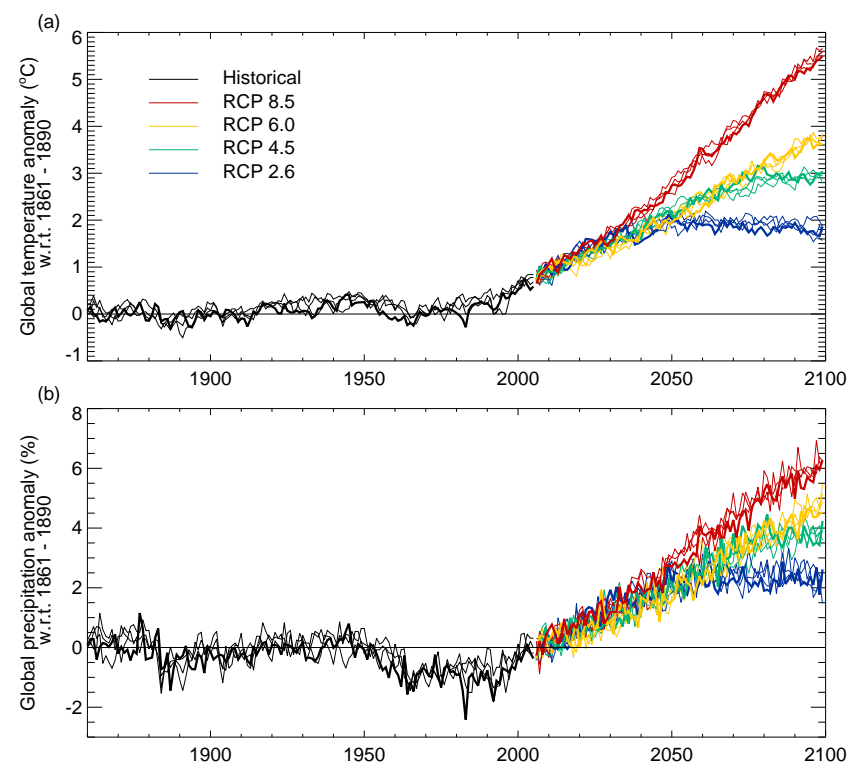

Figure 4. Global annual mean (a) temperature and (b) precipitation changes simulated by HadGEM2-ES in RCP 2.6 (blue), 4.5 (cyan), 6.0 (yellow) and 8.5 (red). Thick lines show the simulations used in the analysis here. Thin lines show additional simulations performed with the same model and same forcing scenarios but slightly different initial conditions, in order to illustrate the magnitude of naturally occurring internal variability in the model.

$60^{\circ} \mathrm{N}$ and northwards in eastern Russia, Canada and Alaska. Along the southern edge of the boreal forest, broadleaf tree cover increases where needleleaf tree decreases, indicating a shift in the competitive balance of the two PFTs. All these changes are consistent with a warming climate, with shrub growth increasingly favoured in current sparsely vegetated areas to the far north, but being outcompeted by needleleaf trees further south - which themselves are outcompeted by broadleaf trees even further south.

Although the changes in boreal and temperate forest and tundra regions are broadly similar under all RCPs, there are also specific differences in RCP4.5 compared to the other $\mathrm{RCPs}$; in RCP4.5 there is an increase in both broadleaf tree and shrub cover in the eastern USA and eastern Russia, and also an increase in needleleaf tree in eastern Russia. This arises from a reduction in anthropogenic disturbance in the land use scenario in RCP4.5 (Hurtt et al., 2010).

Taking northern Europe as an example, the different roles of climate change and land use can be seen. Land use plays little role in RCPs 6.0 and 8.5 (Fig. 9), with average disturbance being unchanged across the 21 st century. In RCP2.6, disturbance increases slightly as a consequence of increased use of land for bioenergy crops. In contrast, disturbance decreases significantly in RCP4.5. There is an overall increase in broadleaf tree cover and an overall decrease in needleleaf tree cover, in all RCPs - the northward expansion of needleleaf tree cover is more than offset by being outcompeted by broadleaf tree further south, consistent with a warming climate. However, climate warming is clearly not the only influence, as the European average increase in broadleaf tree cover is similar in RCP4.5 (with a global warming of approximately $3^{\circ} \mathrm{C}$ by 2100 relative to pre-industrial) and RCP8.5 (with a global warming of approximately $5.5^{\circ} \mathrm{C}$ by 2100 relative to pre-industrial). Although RCP8.5 sees a greater poleward expansion of tree cover, RCP4.5 sees tree cover returning to former agricultural areas as croplands shrink.

Average needleleaf tree cover in Europe declines in all RCPs, with the smallest decline being in RCP4.5 as a result of regrowth in former agricultural regions (alongside broadleaf tree cover) partly offsetting declines due to competition from broadleaf tree in undisturbed areas. In other scenarios, RCP8.5 shows a slightly greater decline consistent with the larger climate change. The needleleaf tree decline in RCP2.6 and RCP6.0 despite large climate change in the latter, because RCP2.6 includes an expansion of land use.

Average shrub cover change in Europe is again dominated by land use change, with increases over most of the 21 st century being seen in RCP4.5, but a small decline beginning towards the end of the century. Again this is consistent with regrowth of shrub in with needleleaf and broadleaf tree in area of former cropland. RCP2.6 shows a small decline in shrub cover, slightly more than RCP8.5 and RCP6.0, again consistent with expanding land use.

In the tropical forests, changes in broadleaf tree cover vary greatly between the different RCPs, with land use playing a major role. RCP2.6 (the scenario with smallest $\mathrm{CO}_{2}$ rise and least global warming) sees widespread reduction in broadleaf tree cover in almost all tropical forest areas in South America, Africa and South East Asia by the end of the 21st century (Fig. 6); only a small region in the north of the central African rainforest sees increased broadleaf tree cover. Most of the declines in forest cover are due to expansion and intensification of agriculture across these regions, including a large increase in bioenergy crops. RCP8.5 also shows extensive declines in broadleaf tree cover in the tropics, again with expansion of land use being a major driver. Some areas of north and west central Africa and north-west Amazonia see increased broadleaf tree cover, where anthropogenic disturbance does not take place in this scenario. Under RCP6.0, the model simulates increased broadleaf tree cover across the central African rainforest and neighbouring savanna regions, and increases in a number of areas in South America except for Amazonia - broadleaf tree cover decreases in eastern Amazonia, and remains largely unchanged in the west. South East Asian broadleaf tree cover declines in RCP 6.0 as in RCP8.5 and RCP2.6. Only in RCP4.5 does South East Asia see increased broadleaf tree cover; in other regions the signal is mixed, with both increases and decreases being seen in different regions of Africa and South America, including in increase in western Amazonia and a decrease in the east.

Despite the clear dominance of land use as the main driver of tropical forest change in these simulations, climate change 
(a)

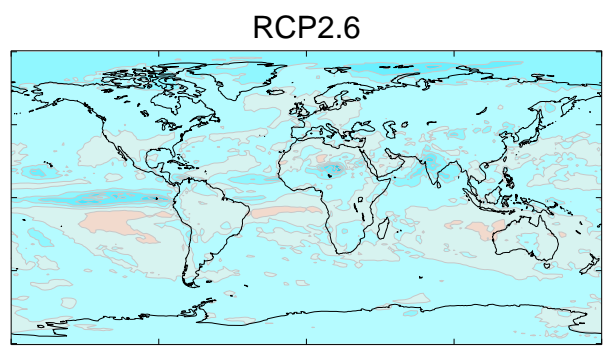

$\begin{array}{lllllllll}-50 & -25 & 0 & 25 & 50 & 75 & 100 & 125 & 150\end{array}$

(c)

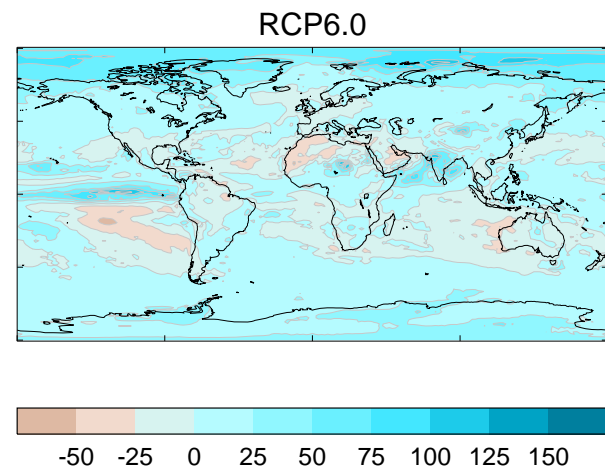

(b)
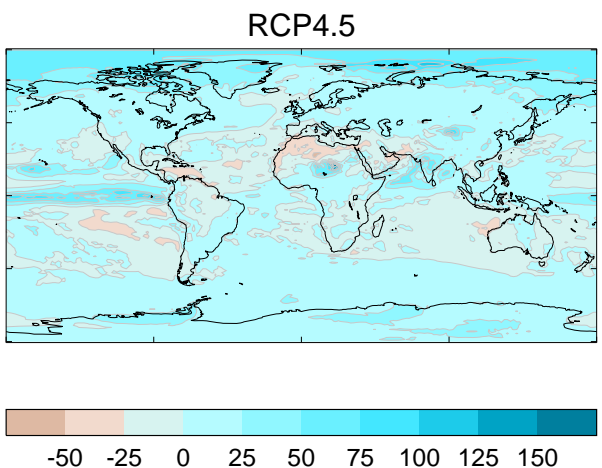

(d)
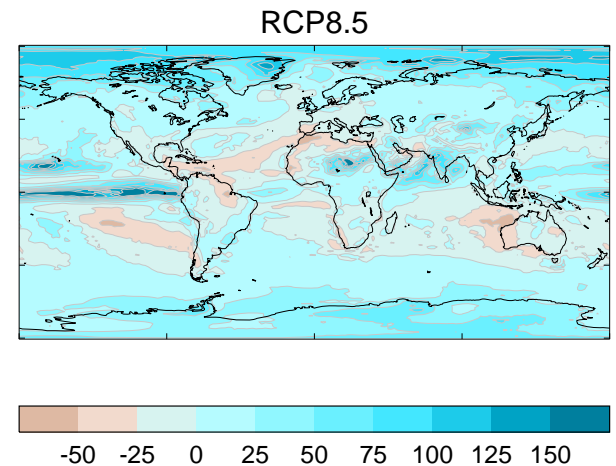

Figure 5. Global patterns of percentage change in annual mean precipitation by 2070-2099 relative to 1971-2000, for (a) RCP2.6, (b) RCP4.5, (c) RCP6.0 and (d) RCP8.5.

may cause conditions to tend towards being less favourable for rainforest in Amazonia because annual mean rainfall is projected to decrease across this region (Fig. 5). However, the impacts of climate change alone on broadleaf tree in this model do not appear to be major by 2100 , even in Amazonia where a previous version of the Met Office Hadley Centre Earth system model (HadCM3LC; Cox et al., 2000) simulated very widespread die back of the forest due to climate change alone (Cox et al., 2004; Betts et al., 2004). HadCM3LC also included the TRIFFID vegetation model, but the version of TRIFFID in HadGEM2-ES features some small further development. In an idealised HadGEM2-ES simulation with a $1 \%$ per year increase in $\mathrm{CO}_{2}$ concentration, although the regional climate of Amazonia became drier and hotter and hence approached less favourable conditions, the impact on broadleaf tree cover was minimal (Good et al., 2013).

To focus on northern South America (including Amazonia and surrounding regions) as an example, Figs. 6, 8 and 10 show very different projected changes in broadleaf tree and shrub cover under the different RCPs. Decreased tree and shrub cover is seen under RCP8.5 and RCP2.6, the scenarios with greatest and least global warming but both with ongoing expansion of agriculture (Fig. 10). Both of these RCPs project similar rates of decline until approximately the 2070s, despite RCP 8.5 featuring a greater increase in land use. This may be due to greater $\mathrm{CO}_{2}$ fertilisation in RCP8.5, as the $\mathrm{CO}_{2}$ rise continues to accelerate until the 2070s, whereas in $\mathrm{RCP} 2.6$ the $\mathrm{CO}_{2}$ rise slows then peaks at approximately $450 \mathrm{ppm}$ mid-century, and gradually declines thereafter. $\mathrm{CO}_{2}$ fertilisation initially enhances NPP in this model, but the effect saturates - the slight acceleration of forest loss after 2070 in RCP8.5 compared to RCP2.6 may therefore reflect the lack of further benefits of $\mathrm{CO}_{2}$ fertilisation at high concentrations, or the beginnings of some climate effects in parts of the region.

In contrast, RCP4.5 and RCP6.0 both project an overall increase in broadleaf tree and shrub cover on average across northern South America, accompanying a decrease in the overall land use area.

Additional simulations with disturbance fixed at the initial state confirm that land use is the main driver of forest cover change in northern South America in HadGEM2-ES, both over the 20th century and the 21st century (Fig. 11).

At the global scale, land use is the dominant influence on tropical and temperate forest cover in these model projections over the 21 st century, as it has been over the 20th century. When disturbance is fixed at the 2000 state, RCP2.6 results in a small increase in broadleaf tree cover, and RCP4.5 and RCP8.5 give slightly larger increases (Fig. 12). 

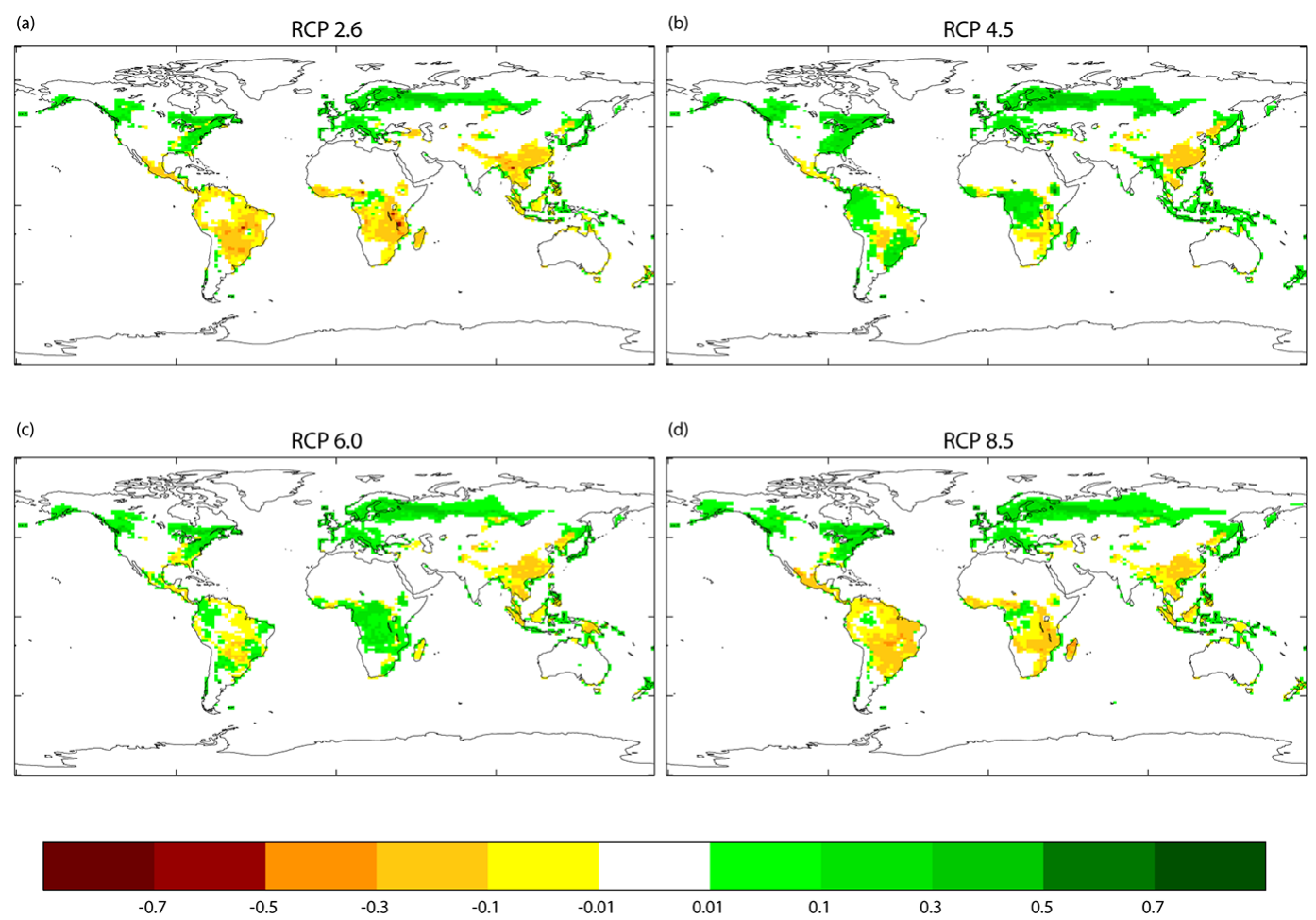

Figure 6. Changes in fractional cover of broadleaf tree by 2070-2099 relative to 1971-2000 simulated by HadGEM2-ES driven by scenarios of greenhouse gas and aerosol concentrations and land use following (a) RCP2.6 (b) RCP4.5 (c) RCP6.0 and (d) RCP8.5.

When disturbance follows the RCP-related land use scenarios, global broadleaf tree cover increases further in RCP4.5 due to reduced disturbance, but decreases further in RCP8.5 and still further in RCP2.6. In HadGEM2-ES driven by the RCP land use scenarios, the greatest loss of broadleaf tree cover occurs in the scenario of early peak and decline of greenhouse gas emissions, because of the role of land use in climate change mitigation.

\subsection{Fire risk}

The vegetation model in HadGEM2-ES does not include a representation of wildfire; it merely assumes a uniform natural disturbance rate. Hence the responses to climate change described above are entirely due to changes in the relative competitiveness of different PFTs as a result of net carbon uptake, through changes in photosynthesis or respiration. However, changes in disturbance regimes may be a crucial aspect of ecosystem change in response to climate change, so the changes simulated by HadGEM2-ES may not represent the full impact of climate change on ecosystems. In order to assess the potential implications of this, we use meteorological variables from HadGEM2-ES to calculate the McArthur Forest Fire Danger Index (FFDI) which is an indicator of the severity of wildfire in forest ecosystems and the difficulty of fire suppression.
Global simulations of FFDI cannot be validated directly as it is not a quantity which is observed; it is an empirical combination of several meteorological variables including temperature, humidity, and windspeed. The global FFDI simulation can however be compared qualitatively with satellite observations of burnt area (Fig. 13) to assess whether the model is producing credible patterns of fire risk in terms of areas of relatively high or low risk. Comparison of the present-day FFDI simulation from HadGEM2-ES (Fig. 14a) with observed burnt area (Fig. 13) suggests that the model is indeed capturing the differences in fire activity within the tropics; for example, a relatively large fraction of burnt area is observed in African savanna regions, and high FFDI is simulated in these regions. In contrast, low observed burnt area and low simulated FFDI are seen in rainforest regions. In western Asia, high FFDI is simulated in regions where high burnt area is seen. However, in temperate and boreal forest regions, patterns of simulated FFDI and observed burnt area do not match, and the variations in burnt area are more closely aligned to patterns of forest cover rather than FFDI. The susceptibility of the landscape to fire and the influence of humans on either ignition or fire suppression are key factors. Hence the simulated changes in FFDI should not be interpreted as predictions of changes in fire activity; instead, they merely give an indication of the implications of simulated changes in weather conditions for the risk of fire. Actual fire activity will depend on other factors such as vegetation cover 

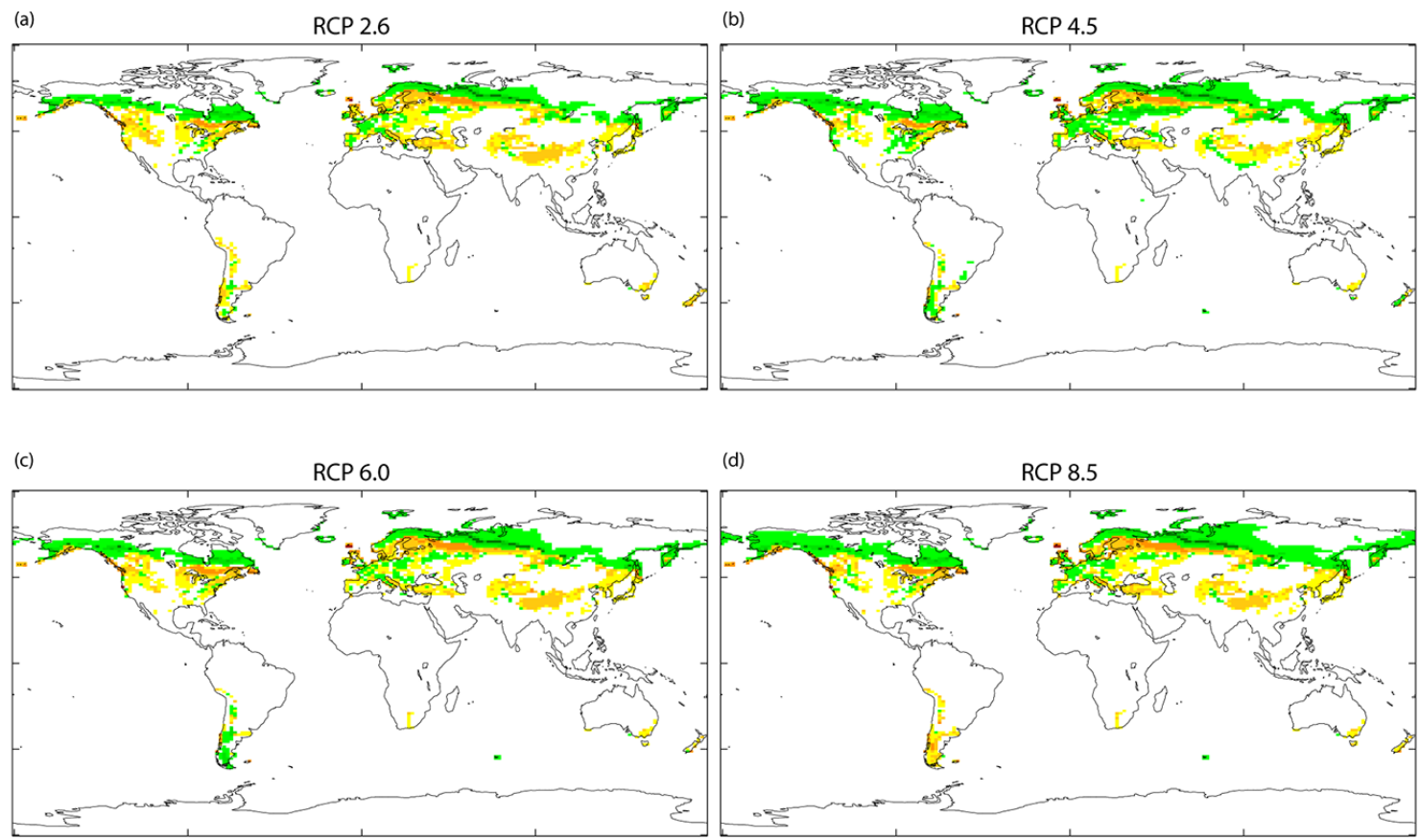

(d)

RCP 8.5
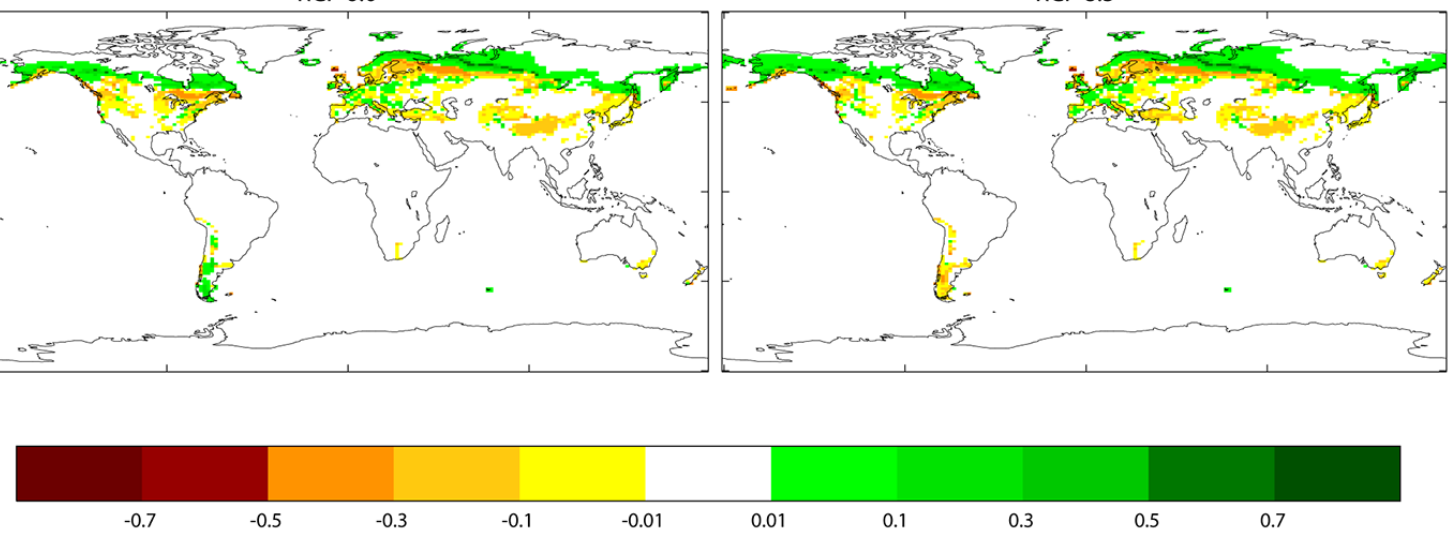

Figure 7. Changes in fractional cover of needleleaf tree by 2070-2099 relative to 1971-2000 simulated by HadGEM2-ES driven by scenarios of greenhouse gas and aerosol concentrations and land use following (a) RCP2.6 (b) RCP4.5 (c) RCP6.0 and (d) RCP8.5.

and type, fuel availability, natural ignition sources, and direct human influence through ignition or fire suppression.

Globally, HadGEM2-ES simulates a general increase in FFDI under all RCPs by the end of the 21 st century, with greater increases at higher levels of global warming (Fig. 14). Under RCP2.6, FFDI increases by approximately 4 units in Europe, western and central USA, eastern and central Brazil, western Asia, central and southern Africa, and most of Australia. This is generally not sufficient to change the annual mean severity assessment of fire risk, although the change may not be uniform throughout the year - changes may be larger or smaller at seasonal or sub-seasonal scales. Annual mean FFDI decreases of a similar magnitude are simulated in northern India and a small region of central Argentina under RCP2.6.

Under RCP8.5, HadGEM2-ES simulates widespread increases in FFDI. Relatively small increases are simulated across most of North America except for the far north of Canada and Alaska, and similar increases are seen across Europe and western and central Asia except for the far north and desert regions. Most of Africa, except for deserts, also sees a simulated increase in FFD, as do most of South America and Australia. Areas of large increase in FFDI (more than 12 units) include eastern Amazonia, southern Africa, west and central Australia, and southern Europe. In some regions the simulated FFDI moves into very high or extreme categories, which would indicate difficulty in controlling fires. Again, it should be noted that this analysis refers to annual mean values - seasonal or daily values are expected to be lower or higher at different times of the year.

Although HadGEM2-ES simulated an expansion of woody vegetation in many regions in all RCPs, this did not include the effects of changes in fire disturbance. The large increases in FFDI in some regions under RCP8.5 suggest that the HadGEM2-ES projections of increased woody vegetation cover may not necessarily be reliable. Further work is required to assess the importance of potential future changes in fire regime for large-scale ecosystems, considering both climate and human drivers.

\subsection{River flows}

TRIP within HadGEM2-ES simulated river flows at individual grid points (Fig. 15), routing the flows across the grid to river outflow points. The simulated river flows can be compared with a data set of present-day river flows from gauging stations (Fig. 16) to evaluate the model performance. Here, modelled river flow is compared against downstream gauges from Dai et al., (2009). To account for biases relating to a mismatch in drained area in the coarse global data set used 

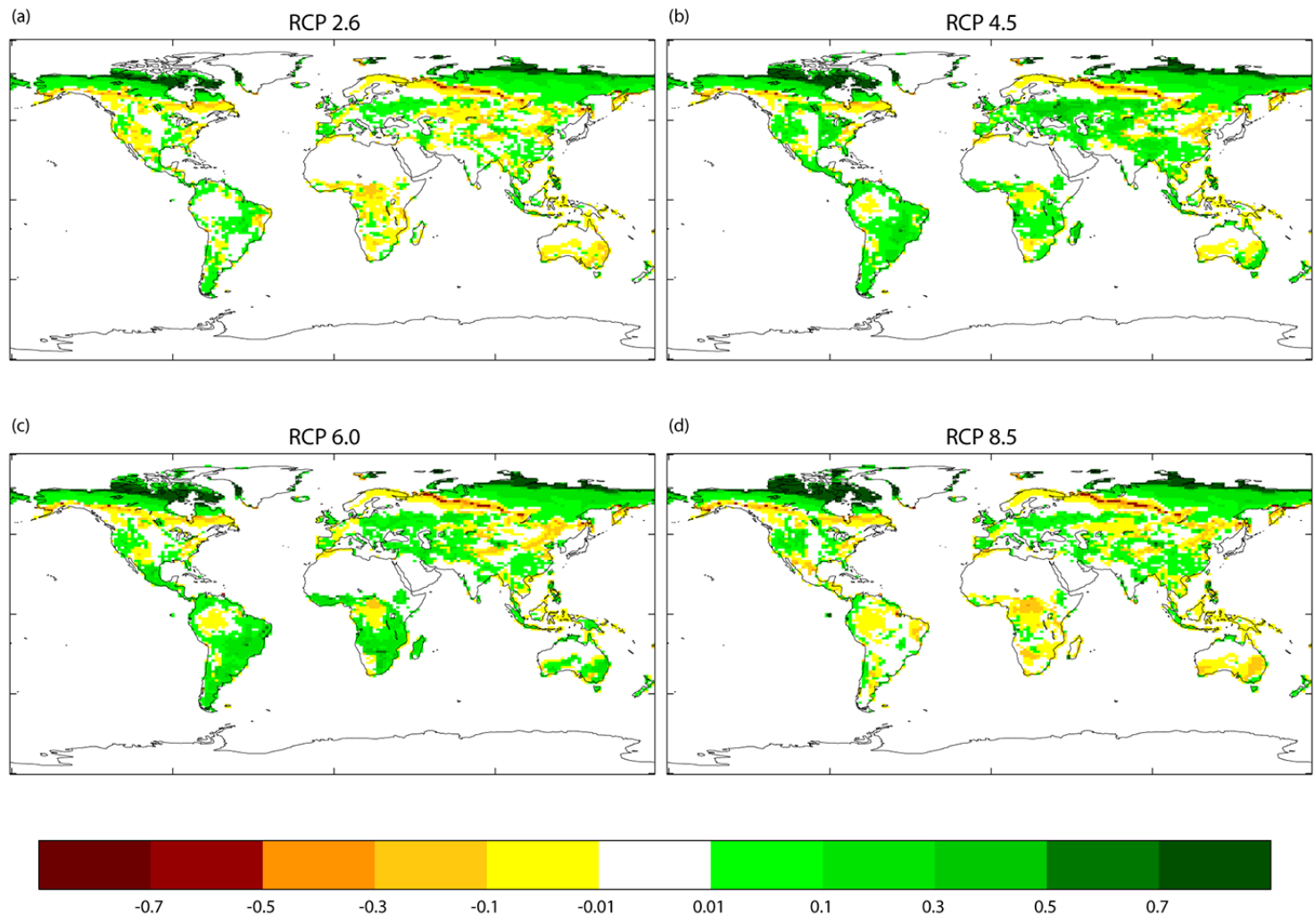

Figure 8. Changes in fractional cover of shrub by 2070-2099 relative to 1971-2000 simulated by HadGEM2-ES driven by scenarios of greenhouse gas and aerosol concentrations and land use following (a) RCP2.6 (b) RCP4.5 (c) RCP6.0 and (d) RCP8.5.
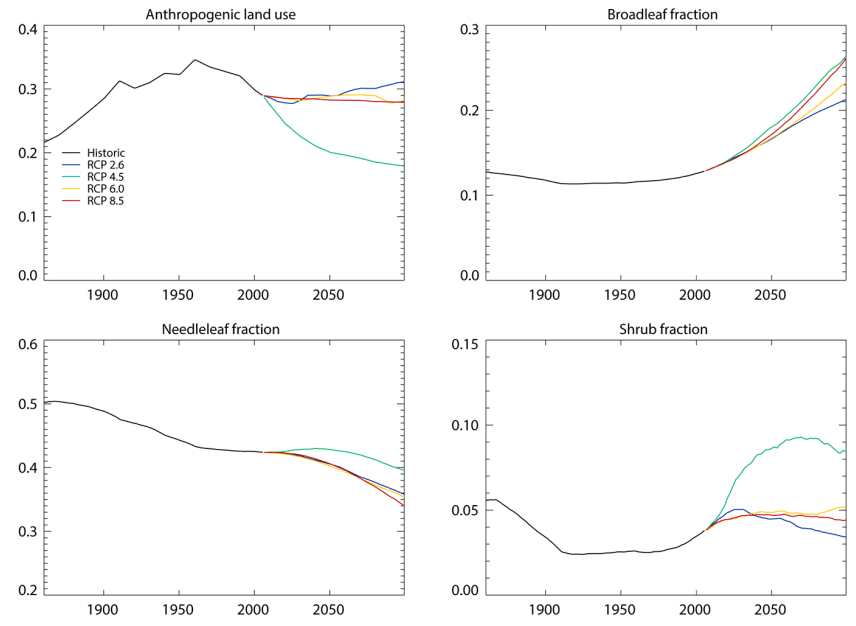

Figure 9. Fractional cover of (a) anthropogenic land use (disturbed fraction), (b) broadleaf tree, (c) needleleaf tree and (d) shrub in HadGEM2-ES in northern Europe under the 4 RCPs. Note difference scales used on the $y$ axes.

in HadGEM2-ES the simulated riverflow data is re-weighted to the drained area given in Dai et al. (2009).

Model performance for individual gauging stations varies, with simulated river flows being too high at some stations
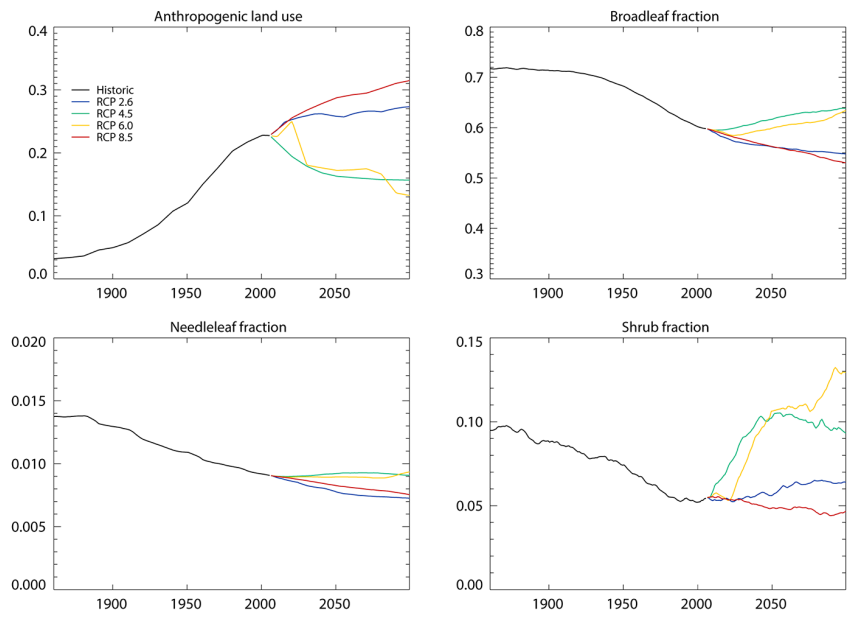

Figure 10. Fractional cover of (a) anthropogenic land use (disturbed fraction), (b) broadleaf tree, (c) needleleaf tree and (d) shrub in HadGEM2-ES in northern South America under the 4 RCPs. Note difference scales used on $y$ axes.

and too low at others, and overall the model bias is more towards the low side (Fig. 16). For the largest river (the Amazon), the simulation agrees with observations within $1 \%$, and for many other large rivers the agreement is within $10-30 \%$. 


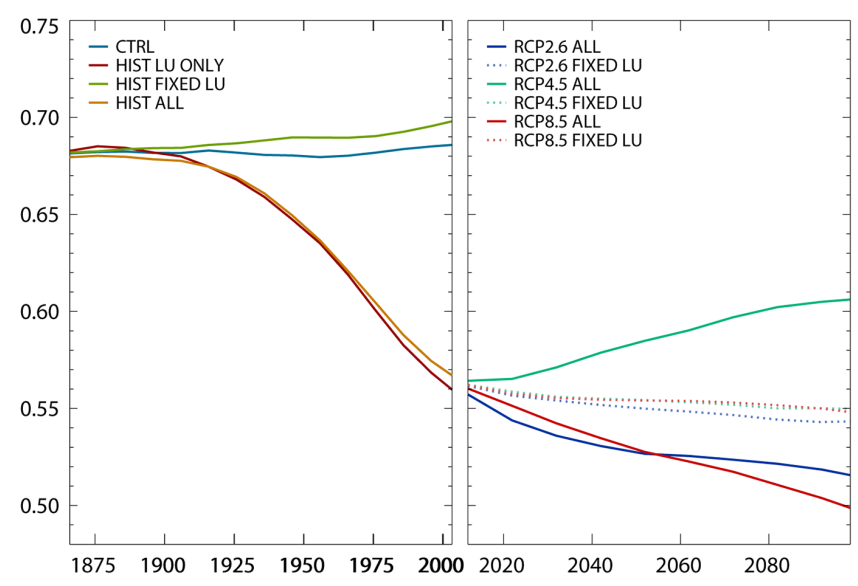

Figure 11. Fractional cover of broadleaf tree in northern South America simulated by HadGEM2-ES under historical forcings (left panel) and 3 of the 4 RCPs (right panel) with different combinations of climate and land use (LU) drivers. In the left panel, historical simulations were driven by; historical land use only, with no change in greenhouse gas concentrations (HIST LU ONLY: red line); greenhouse gas changes but with land use fixed at the initial state in 1860 (HIST FIXED LU: green line); and a combination of the previous two (HIST ALL: yellow line). The control simulation with no external forcing is also shown (CTRL: blue line). In the right panel, dark lines (ALL) show simulations driven by greenhouse gas and land use changes for RCP2.6, RCP4.6 and RCP8.5, and faded lines (FIXED LU) show simulations driven with greenhouse gas changes but with land use fixed at the 2005 state.

Percentage differences are generally larger for smaller rivers, as the influence of local precipitation biases becomes relatively more significant.

The global total river flow is simulated to remain approximately constant over the 21 st century under RCP2.6, with some decadal variability (Fig. 17). Under other RCPs, simulated global river flow generally increases over the 21 st century, with the final increase at the end of the century being larger at higher levels of global warming. However, the relative global runoff increase in the different RCPs varies over the century; while RCP8.5 consistently gives the largest increase in runoff, RCP4.5 results in larger increases than RCP6.0 until the 2070s. It is noted that the global mean temperature projections in RCP4.5 and RCP6.0 also remain similar until that time, with a slightly larger warming in RCP4.5 than RCP6.0 in the mid-21st century.

Similar results are seen at continental scales in Africa, Asia, and North America (Fig. 18, Table 2), with a general increase in runoff by the 2070-2099 which increases with the level of global warming at that time. However, as with global runoff, the differences between RCPs are not consistent over the 21st century - for example, in North America, the largest increase in runoff by the 2040-2069 is simulated in RCP2.6. Continental river outflows in Australia, Europe, and South America show no consistent relationship with global warm-

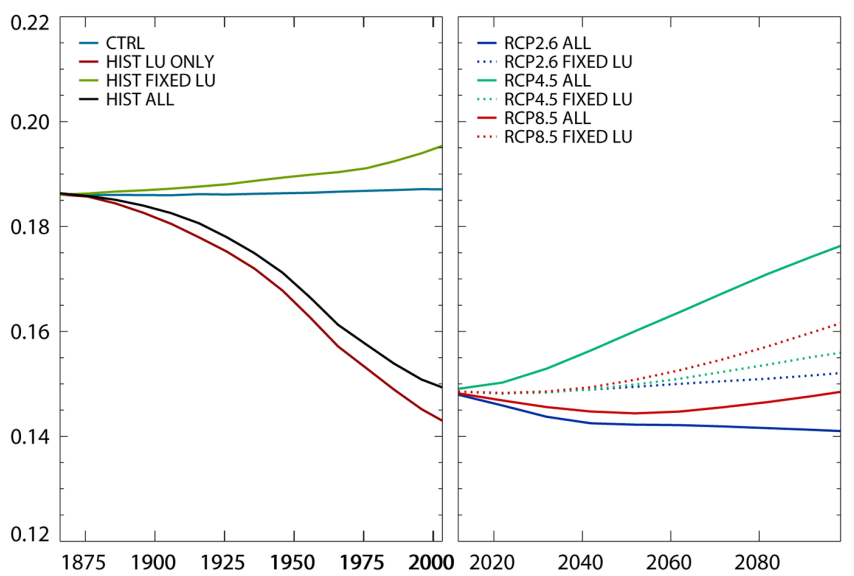

Figure 12. Global fractions of broadleaf tree simulated by HadGEM2-ES under historical forcings (left panel) and 3 of the 4 RCPs (right panel) with different combinations of climate and land use (LU) drivers. In the left panel, historical simulations were driven by; historical land use only, with no change in greenhouse gas concentrations (HIST LU ONLY: red line); greenhouse gas changes but with land use fixed at the initial state in 1860 (HIST FIXED LU: green line); and a combination of the previous two (HIST ALL: yellow line). The control simulation with no external forcing is also shown (CTRL: blue line). In the right panel, dark lines (ALL) show simulations driven by greenhouse gas and land use changes for RCP2.6, RCP4.6 and RCP8.5, and faded lines (FIXED LU) show simulations driven with greenhouse gas changes but with land use fixed at the 2005 state.

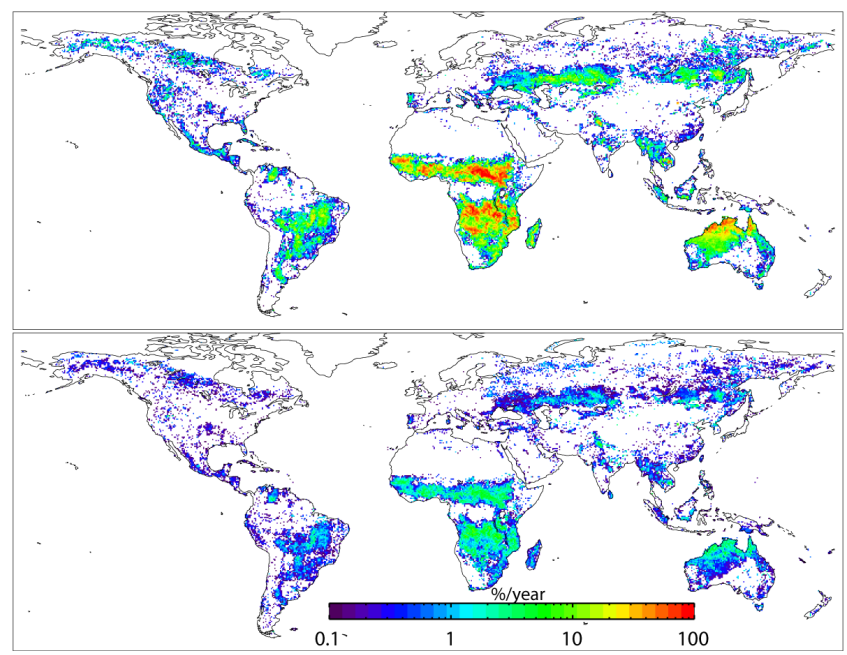

Figure 13. The 1997-2008 mean annual burned area (\% of grid cell) from four satellite data sets (top) and associated one-sigma uncertainties (bottom). Reproduced with permission from Giglio et al. (2010).

ing or RCPs either over time or across RCPs (Fig. 18, Table 2).

Consistent geographical patterns of projected river flow change can be seen across the 21 st century and across all 

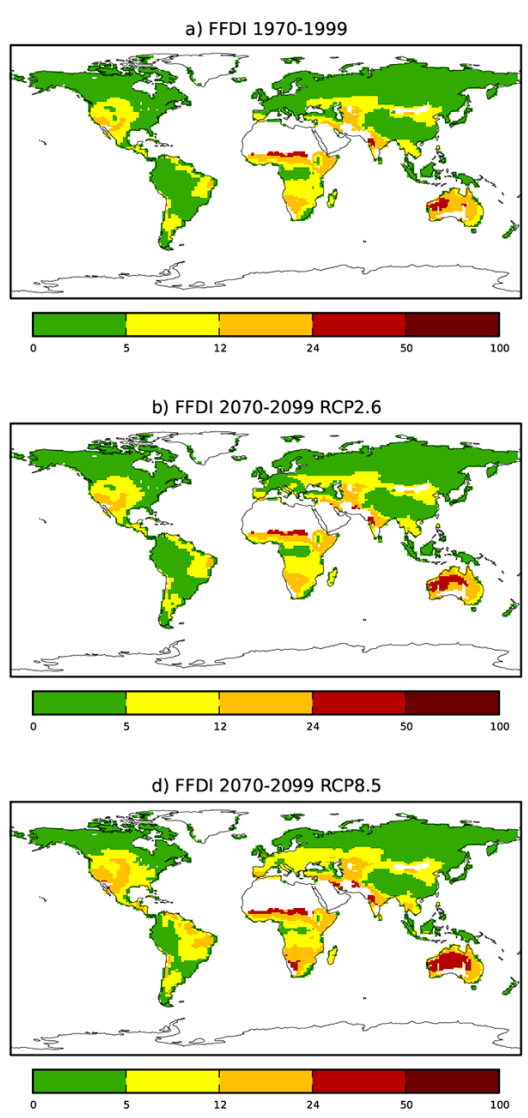

McArthur Forest Fire Danger Index

$0-5$ : low

5-12: moderate

12-24: high

24-50: very high

50-100: extreme
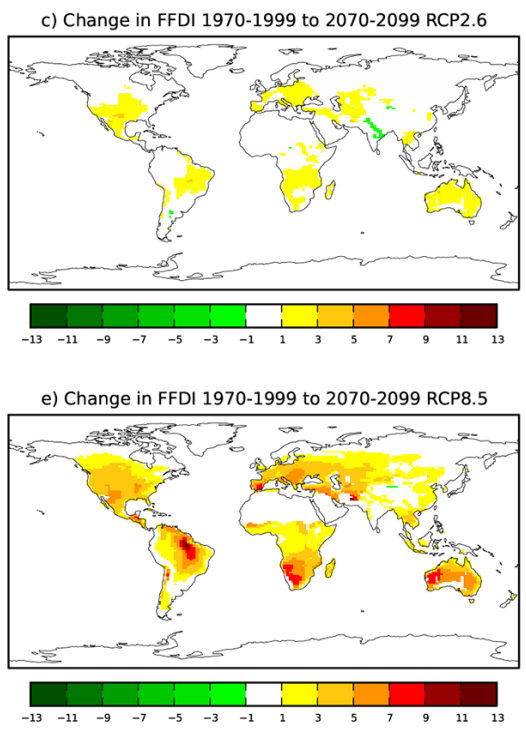

Figure 14. 30-year mean McArthur Forest Fire Danger Index (FFDI) simulated by HadGEM2-ES for (a) 1970-1999 (b) 2070-2099 for RCP2.6 and (c) 2070-2099 for RCP8.5. Changes in FFDI between 1970-1999 and 2070-2099 for (d) RCP2.6 and (e) RCP8.5

RCPs in many regions (Fig. 19). To first order, the geographical variations in river flow change are consistent with those in precipitation (Fig. 5). The increase in global mean precipitation over the century is probably the primary driver of the global river flow increase, although it is noted that the HadGEM2-ES land-surface scheme simulates increased water use efficiency of vegetation under higher $\mathrm{CO}_{2}$ concentrations which partly offsets increases in evaporation due to warming. This effect increases simulated runoff in earlier Met Office Hadley Centre models (Betts et al., 2007).

Overall, the patterns of projected river flow change are consistent with previous projections (Nohara et al., 2006; Kundzewicz et al., 2007), although in some regions the range of potential changes is large. The approach used here, of simulating runoff within the GCM fully consistently with the climate simulations, may be useful in narrowing the range of uncertainty by excluding future projections in which climate and hydrological changes are inconsistent. It will be particularly instructive to compare with studies which use the meteorological outputs of HadGEM2-ES to drive separate hydrological models. One such opportunity is provided by comparing against the result of Arnell and Lloyd-Hughes (2012) who used HadGEM2-ES meteorological outputs as inputs to the MacPDM hydrological model (Gosling et al., 2011), which calculates evapotranspiration, runoff, and river flow. Arnell and Lloyd-Hughes (2012) found MacPDM to simulate decreased runoff over a greater proportion of the global land surface than increased runoff by 2050 , and for the ratio of decreased to increased runoff area to be greater under higher emissions scenarios (Table 3). MacPDM is therefore simulating an increased tendency towards drier conditions at the global scale when driven by HadGEM2-ES climate change. However, runoff results direct from HadGEM2-ES itself suggest the opposite; HadGEM2-ES, simulates increased runoff over a greater proportion of the land surface, and the ratio of increased to decreased runoff area generally increases at under higher emissions scenarios. HadGEM2-ES itself is therefore simulating an increased tendency towards wetter conditions. This may provide important context for other assessments of hydrological impacts of climate change using HadGEM2-ES meteorological outputs.

It is important to note that this analysis has focussed only on annual mean river flow changes, but impacts may also depend on shifts in seasonality. 


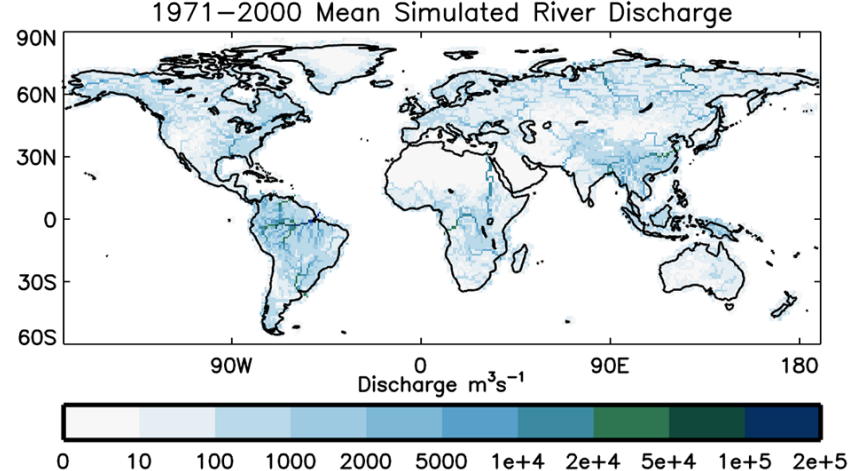

Figure 15. Mean river flow $\left(\mathrm{m}^{3} \mathrm{~s}^{-1}\right)$ over $1971-2000$ simulated by HadGEM2-ES.

\section{Discussion}

The impacts of climate change on global-scale terrestrial ecosystems simulated by HadGEM2-ES are generally consistent with previous projections, particularly regarding a poleward shift of temperate and boreal ecosystems. A key difference compared to the previous Met Office Hadley Centre Earth system model HadCM3LC is the lack of climatedriven Amazon forest dieback in HadGEM2-ES, mainly due to differences in the regional climate change simulated over Amazonia and also differences in the TRIFFID vegetation model. Other vegetation models also simulated largescale forest loss under the climate changes projected by the HadCM3 family of models (Lapola et al., 2009), indicating that the main cause of simulated forest loss was the regional climate change in HadCM3LC as opposed to an oversensitive response by TRIFFID. Other climate models had not produced such a die back result (Lapola et al., 2009), so HadGEM2-ES agrees more with the wider set of modelling studies than its predecessor. Vegetation-climate feedbacks played a role in magnifying the loss of Amazon forest in HadCM3LC (Betts et al., 2004), but in HadGEM2-ES such feedbacks do not have the opportunity to play a role because the climate change and vegetation response are not sufficient to initiate the dieback.

In some ways, HadGEM2-ES also generally agrees with previous projections in simulating increased runoff in northern North America northern Asia and the Indian subcontinent, and decreased runoff in Europe. However, there are important differences, especially when compared to another hydrological model driven by HadGEM2-ES meteorological outputs. In terms of the relative proportions of global land undergoing either increased or decreased runoff, HadGEM2ES projects a dominance of wetting conditions (more area with increased runoff) and this wetting becoming greater under higher emissions scenarios. In contrast, the MacPDM hydrological model driven by HadGEM2-ES meteorology projects a dominance of drying conditions which becomes greater with higher emissions. From this it is not possible to assess whether MacPDM is either more or less realistic than the HadGEM2-ES land-surface scheme in terms of its response to a particular climate change, so it not clear whether a wetting or drying trend is more realistic. However, it seems inevitable that the evaporation simulated by MacPDM will be inconsistent with that simulated by HadGEM2-ES, and hence the hydrological cycle will not be conserved in the HadGEM2-ES-MacPDM results, and indeed water will be "lost" from the system; greater runoff decreases in MacPDM compared to HadGEM2-ES imply greater evaporation in MacPDM, but this is not adding to the precipitable water in HadGEM2-ES so is not allowing for increased precipitation as might be the case if MacPDM were the landsurface scheme of HadGEM2-ES. This may therefore indicate that the extent of decreased runoff in MacPDM driven by HadGEM2-ES should be treated with some caution, as HadGEM2-ES may not have simulated such large precipitation decreases if using evaporation from MacPDM. However, this is a preliminary conclusion and requires further investigation.

The dominance of land use over climate change as a driver of large-scale ecosystem impacts is an important result. Since the vegetation responses to climate are similar in all RCPs, including the aggressive mitigation scenario RCP2.6, this appears to imply that climate change mitigation policies may have little effect on reducing the impact of climate change on global biome distributions, at least within this century. A greater impact on global vegetation cover appears to come from the direct effects of anthropogenic land use, especially when land use is used as a tool for climate change mitigation. This may indicate that greater impacts on global-scale vegetation cover may arise from the use of the land in attempting to avoid climate change than from the impacts of climate change itself.

However, if the simulated FFDI changes are realistic then this may imply potential impacts of climate change on ecosystems that are very different to those simulated directly by HadGEM2-ES on the basis of plant physiological processes alone. The potential for changes in meteorological fire danger, and hence ecosystem disturbance regimes, appears to be larger under higher emissions scenarios. In the absence of increasing anthropogenic disturbance, HadGEM2-ES simulates increased forest cover in many regions, but this may be inconsistent with an annual mean increase in FFDI which would seem to indicate a general increased risk of wildfire and hence a change in the disturbance regime. In particular, in regions where human disturbance is already present or projected to increase under the RCP land use scenarios, this may affect rates of ignition and hence increase the probability of fire-supporting weather conditions resulting in actual fires. For example, in Amazonia and Indonesia, major droughts have led to increased wildfire impacts originating from deforestation activity - while humans provided the ignition source, weather conditions facilitated greater fire spread. In the temperate and boreal regions, studies with other mod- 
Table 2. 15) Percentage change in continental river discharge simulated by HadGEM2-ES for 30-year means relative to 1970-2000 for the 4 RCP scenarios.

\begin{tabular}{llrrrrrrr}
\hline RCP & Period & Africa & Asia & Australia & Europe & N. America & S. America & Globe \\
\hline 2.6 & $2010-2039$ & 6.73 & 3.42 & 6.24 & -4.84 & 11.92 & -2.44 & 2.63 \\
2.6 & $2040-2069$ & 1.93 & 6.14 & -4.45 & -1.26 & 17.73 & -4.29 & 2.81 \\
2.6 & $2070-2099$ & 3.12 & 8.96 & 5.73 & -5.14 & 14.07 & -5.70 & 2.46 \\
\hline 4.5 & $2010-2039$ & 6.32 & 5.33 & -2.57 & 1.07 & 8.26 & -0.93 & 2.94 \\
4.5 & $2040-2069$ & 14.23 & 8.47 & 9.40 & -7.53 & 17.35 & -1.84 & 5.18 \\
4.5 & $2070-2099$ & 12.77 & 13.28 & 11.27 & 2.29 & 24.51 & -2.14 & 7.87 \\
\hline 6.0 & $2010-2039$ & 11.33 & 3.20 & 5.57 & -1.60 & 11.13 & -1.48 & 2.89 \\
6.0 & $2040-2069$ & 20.12 & 2.78 & -3.46 & -1.67 & 16.81 & -3.51 & 3.55 \\
6.0 & $2070-2099$ & 22.02 & 16.16 & 5.78 & -1.25 & 29.16 & -0.82 & 10.23 \\
\hline 8.5 & $2010-2039$ & 10.78 & 5.31 & -1.45 & -0.82 & 11.32 & -2.06 & 3.59 \\
8.5 & $2040-2069$ & 14.51 & 11.23 & 6.52 & -3.50 & 24.51 & -0.88 & 7.82 \\
8.5 & $2070-2099$ & 25.31 & 22.29 & 8.78 & 1.24 & 44.06 & -4.34 & 13.62 \\
\hline
\end{tabular}

Table 3. Percentage of global land (excluding Antarctica) undergoing increased or decreased runoff by 2050 in HadGEM2-ES and MacPDM driven by HadGEM2-ES (Arnell and Lloyd-Hughes, 2012).

\begin{tabular}{lrrrr}
\hline Model & RCP2.6 & RCP4.5 & RCP6.0 & RCP8.5 \\
\hline Increased runoff (\% of area) & & & & \\
\hline HadGEM2-ES & 59 & 61 & 60 & 63 \\
MacPDM driven & 29 & 25 & Not available & 24 \\
by HadGEM2-ES & & & & \\
\hline Decreased runoff (\% of area) & & & 38 & 35 \\
\hline HadGEM2-ES & 38 & 36 & Not available & 61 \\
MacPDM driven & 53 & 56 & & \\
by HadGEM2-ES & & & & \\
\hline
\end{tabular}

els also project an increase in fire risk in temperature and boreal regions due to climate change (Kloster et al., 2012; Moritz et al., 2012). However, there is less agreement on the sign of projected change in fire risk in the tropics, with increased fire risk projected with some other models (Kloster et al., 2012) but decreased fire risk projected with several others (Moritz et al., 2012). Further investigation is required to assess whether these differences arises from the climate models or different fire metrics. However, on the basis of these preliminary results, it seems appropriate to investigate the role of fire in ecosystem disturbance in modifying the vegetation cover change projections in Earth system models. As well as affecting ecosystem responses to climate and land use change, changes in fire regime may also feed back on climate through emissions of $\mathrm{CO}_{2}$ and aerosols.

\section{Conclusions}

The impacts of climate change on global-scale terrestrial ecosystems and river flows simulated by HadGEM2-ES are generally consistent with previous projections, and the lack of climate-driven dieback in the Amazon forest means that projected ecosystem impacts are now more consistent with other models than with the previous Met Office Hadley Centre model. An important difference between the balance of projected wetting and drying in HadGEM2-ES compared to one hydrological model driven by HadGEM2-ES meteorology is noted, illustrating the importance of consistency between land hydrological processes and the overlying climate change. HadGEM2-ES projects a greater proportion of the global land surface to undergo increased runoff than decreased runoff, especially at higher emissions scenarios.

The approach of prioritising full internal consistency within the climate system may make the projected changes more plausible in terms of maintaining conservation in the water cycle and consistency between land-surface processes and the overlying atmosphere. However in some cases this may be at the cost of realistic baseline states at the presentday, due to systematic biases in climate models. Further work is required to address the relative potential importance of these issues; nevertheless, as improvements in climate mod- 


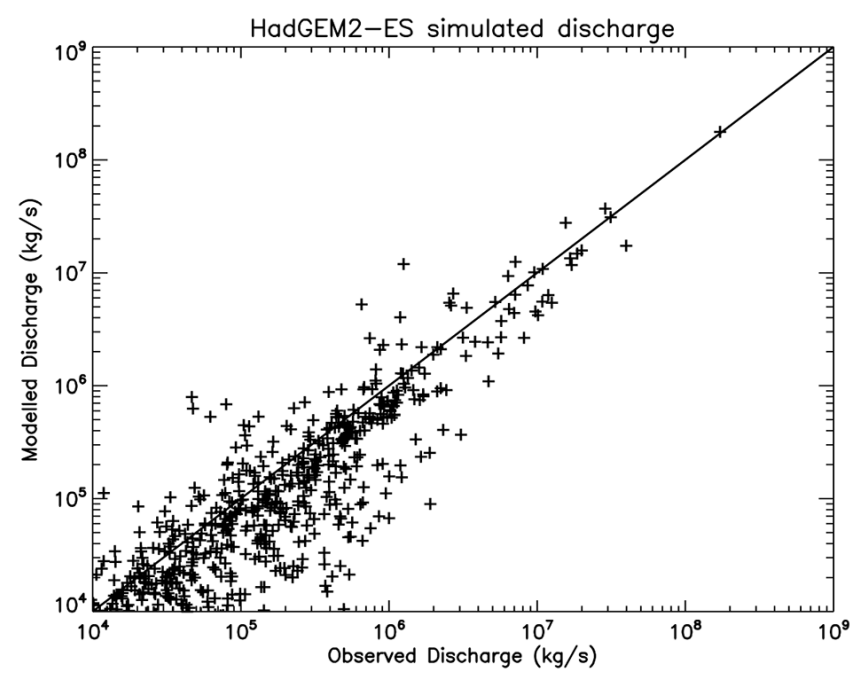

Figure 16. Simulated mean river discharge from the historical HadGEM2-ES simulation against observations from Dai et al. (2009).

elling continue, regional biases in climate simulations can be expected to continue to decrease, so this may become less of a concern in future. The present study will be useful for comparison against other projections of impacts of climate change using separate models driven by meteorological outputs of HadGEM2-ES and other Earth system models (e.g. Friend et al., 2014; Schewe et al., 2014). Since HadGEM2ES is part of the CMIP5 multi-model ensemble, a number of such studies can be expected to become available in the near future.

Meteorologically-defined wildfire risk is projected to increase in all regions under our HadGEM2-ES projections; previous studies draw similar conclusions in the temperate and boreal regions (Moritz et al., 2012; Kloster et al., 2012) but vary between projecting increased (Kloster et al., 2012) and decreased (Moritz et al., 2012) fire risk in the tropics. Such studies are few in number so assessment against a previous consensus is difficult. This may have implications for the projections of ecosystem change, since wildfire is not included as an impact on vegetation in HadGEM2-ES.

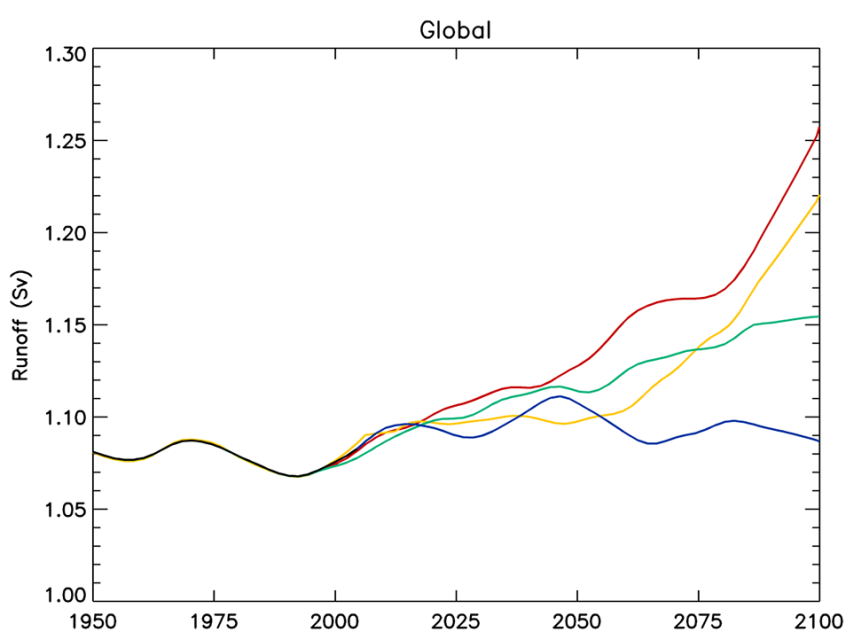

Figure 17. Global total river flow simulated by HadGEM2-ES under historical forcing prior to 2000 and the RCPs over the 21 st century.

The importance of different emissions scenarios, as expressed with the RCPs, varies according to region and which impact is examined. In some regions, river flow changes (either increases or decreases) become larger with increased global warming, but in other regions there is no clear relationship with global mean temperature. Global ecosystem responses to climate change appear to be similar in all RCPs until 2100; however, meteorologically-defined fire risk increased more with higher levels of global warming. In the model, the dominant impact on large-scale ecosystem distribution arises from the direct effects of land use change, and the greatest impact occurs in the scenario in which land use change is large due to the use of bioenergy for climate change mitigation. Hence, in this Earth system model, some of the impacts of climate change are reduced by following scenarios of low emissions, but the use of land use change in achieving very low emissions itself exerts major impacts. In this model, and within this century, the different impacts on ecosystems between the RCPs arises much more from differences in land use than from different levels of global warming. Clearly this potentially has major implications for the costs and benefits of climate mitigation policy, so further investigation of these issues with independent models and methods is recommended. 

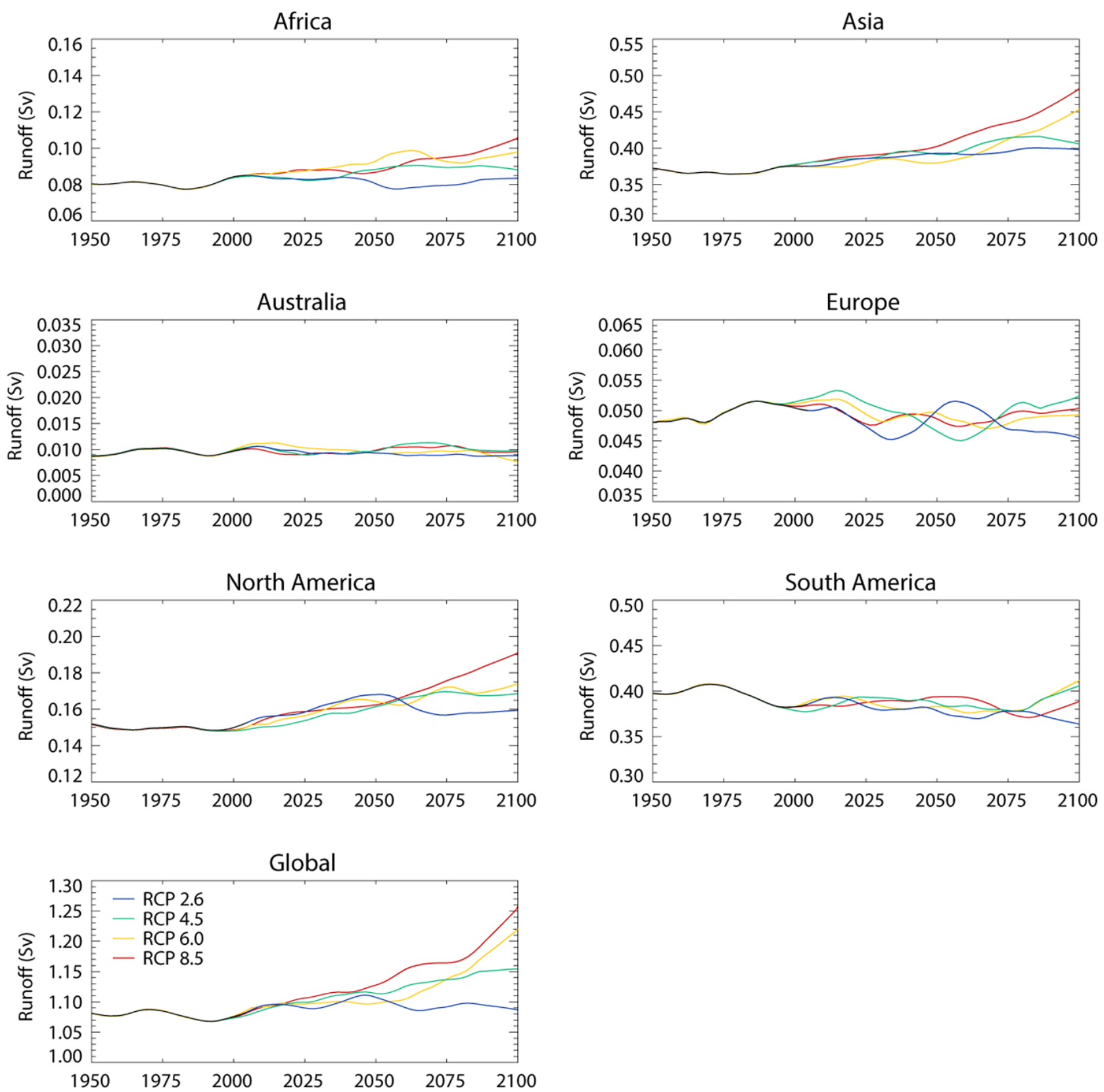

Figure 18. Total river outflow (Sverdrups) for Africa, Asia, Australia, Europe, North America, South America and the globe, simulated by HadGEM2-ES under historical forcing prior to 2000 and thereafter under RCP2.6 (blue), RCP4.0 (cyan), RCP6.0 (yellow) and RCP8.5(red). 
RCP 2.6 2010-2039

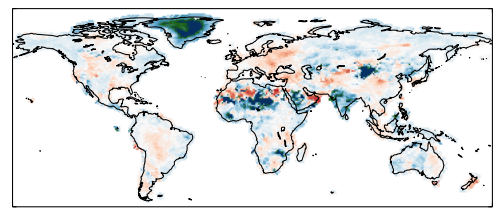

RCP 4.5 2010-2039

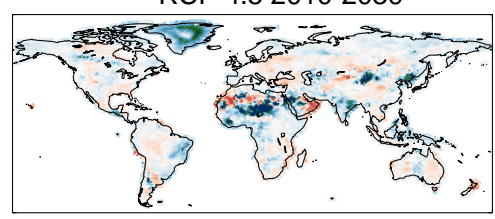

RCP $6.02010-2039$

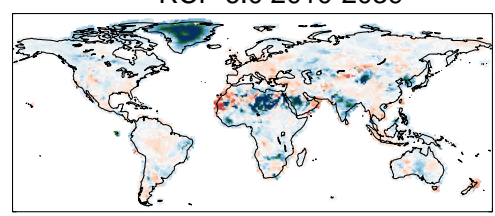

RCP 8.5 2010-2039

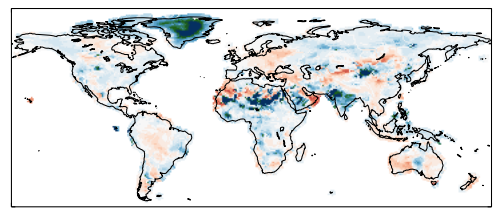

RCP 2.6 2040-2069

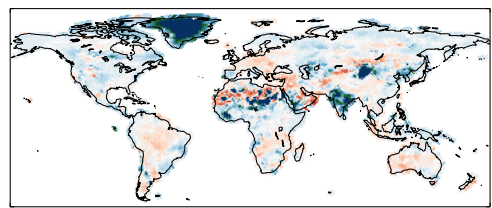

RCP 4.5 2040-2069

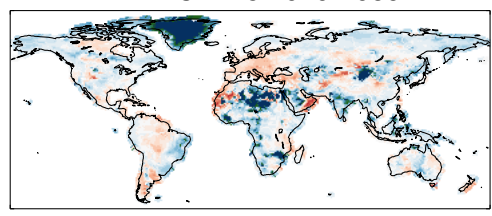

RCP $6.02040-2069$

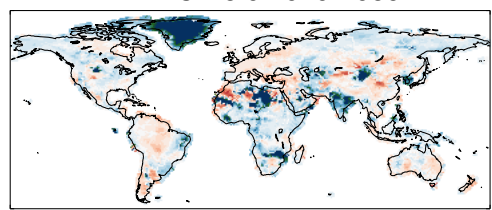

RCP 8.5 2040-2069

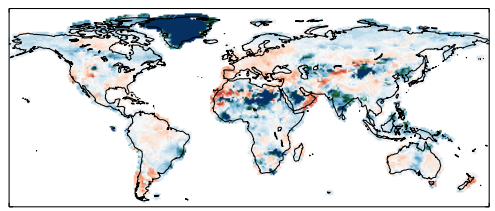

RCP 2.6 2070-2099

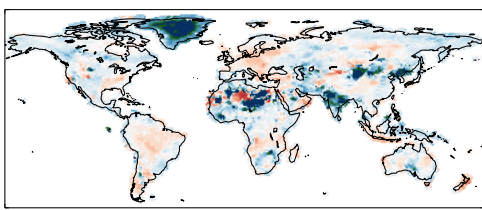

RCP 4.5 2070-2099

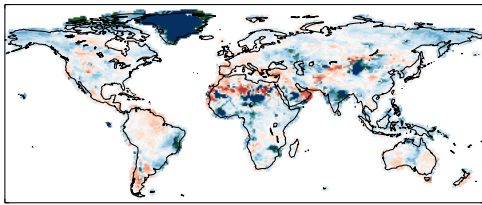

RCP 6.0 2070-2099

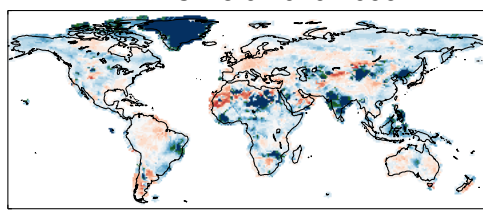

RCP 8.5 2070-2099

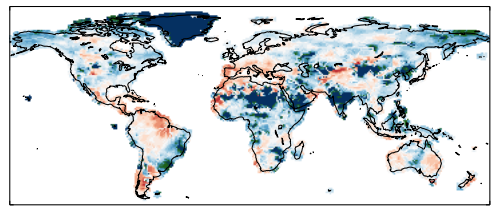

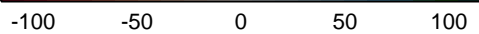

Figure 19. Percentage change in catchment river discharge simulated by HadGEM2-ES for 30-year means relative to 1971-2000 for the 4 RCP scenarios. 
Acknowledgements. The authors thank J. Caeser and E. Palin for preparation of Figs. 2, 4 and 5, F. Pacifico for performing the simulations with fixed land use, and C. Jones for leading the production of the HadGEM2-ES RCP simulations and for discussion. This work was supported by the Joint DECC/Defra Met Office Hadley Centre Climate Programme (GA01101).

Edited by: M. Williams

\section{References}

Alo, C. A. and Wang, G.: Potential future changes of the terrestrial ecosystem based on climate projections by eight general circulation models, J. Geophys. Res., 113, G01004, doi:10.1029/2007JG000528, 2008

Arnell, N. W. and Lloyd-Hughes, B.: Global-scale impacts of climate change at different levels of forcing, AVOID project report AV/WS2/D1/R35, available for download from http://www.avoid.uk.net/2012, 2012.

Bergengren, J., Waliser, D., and Yung, Y.: Ecological sensitivity: a biospheric view of climate change, Clim. Change, 107, 433-457, 2011.

Bertrand, R., Lenoir, J., Piedallu, C., Riofrío-Dillon, G., de Ruffray, P., Vidal, C., Pierrat, J. C., and Gégout, J. C.: Changes in plant community composition lag behind climate warming in lowland forests, Nature 479, 517-20, 2011.

Betts, R. A., Cox, P. M., Collins, M., Harris, P. P., Huntingford, C., and Jones, C. D.: The role of ecosystem-atmosphere interactions in simulated Amazonian precipitation decrease and forest dieback under global climate warming, Theor. Appl. Climatol., 78, 157-175, 2004.

Betts, R. A., Boucher, O, Collins, M., Cox, P. M., Falloon, P. D., Gedney, N., Hemming, D. L., Huntingford, C., Jones, C. D., Sexton, D. M. H., and Webb, M. J.: Projected increase in future river runoff through plant responses to carbon dioxide rise, Nature, 448, 1037-1042, 2007.

Caeser, J., Palin, E., Liddicoat, S., Lowe, J., Burke, E., Pardaens, A., Sanderson, M., and Kahana, R.: Response of the HadGEM2 Earth System Model to Future Greenhouse Gas Emissions Pathways to the Year 2300, J. Climate, 26, 3275-3284, 2013.

Christensen, J. H., Hewitson, B., Busuioc, A., Chen, A., Gao, X., Held, I., Jones, R., Kolli, R. K., Kwon, W.-T., Laprise, R., Magaña Rueda, V., Mearns, L., Menéndez, C. G., Räisänen, J., Rinke, A., Sarr, A., and Whetton, P.: Regional Climate Projections, in: Climate Change 2007: The Physical Science Basis, Contribution of Working Group I to the Fourth Assessment Report of the Intergovernmental Panel on Climate Change, edited by: Solomon, S., Qin, D., Manning, M., Chen, Z., Marquis, M., Averyt, K. B., Tignor, M., and Miller, H. L., Cambridge University Press, Cambridge, United Kingdom and New York, NY, USA, 2007

Collins, W. J., Bellouin, N., Doutriaux-Boucher, M., Gedney, N., Halloran, P., Hinton, T., Hughes, J., Jones, C. D., Joshi, M., Liddicoat, S., Martin, G., O'Connor, F., Rae, J., Senior, C., Sitch, S., Totterdell, I., Wiltshire, A., and Woodward, S.: Development and evaluation of an Earth-System model - HadGEM2, Geosci. Model Dev., 4, 1051-1075, 2011.

Colwell, R. K., Brehm, G., Cardelús, C. L., Gilman, A. C., and Longino, J. T.: Global Warming, Elevational Range Shifts, and
Lowland Biotic Attrition in the Wet Tropics, Science, 322, 258261, 2008.

Cox, P.: Description of the TRIFFID dynamic global vegetation model, Hadley Centre Technical Note No. 24 http://www. metoffice.gov.uk/archive/hadley-centre-technical-note-24, 2001.

Cox, P. M., Betts, R. A., Bunton, C. B., Essery, R. L. H., Rowntree, P. R., and Smith, J.: The impact of new land surface physics on the GCM simulation of climate and climate sensitivity, Clim. Dyn., 15, 183-203, 1999.

Cox, P. M., Betts, R. A., Jones, C. D., Spall, S. A., and Totterdell, I. J.: Acceleration of global warming due to carbon-cycle feedbacks in a coupled climate model, Nature, 408, 184-187, 2000.

Cox, P. M., Betts, R. A., Collins, M., Harris, P. P., Huntingford, C., and Jones, C. D.: Amazonian forest dieback under climate -carbon cycle projections for the 21st Century, Theor. Appl. Climatol., 78, 137-156, 2004.

Dai, A., Qian, T., Trenberth, K. E., and Milliman, J. D.: Changes in continenta freshwater discharge from 1948-2004, J. Climate, 22, 2773-2791, 2009.

Ellis, E. C., Klein Goldewijk, K., Siebert, S., Lightman, D., and Ramankutty, N.: Anthropogenic transformation of the biomes, 1700-2000, Glob. Ecol. Biogeogr., 19, 589-606, 2010.

Essery, R. L. H., Best, M. J., Betts, R. A., Cox, P. M., and Taylor, C. M.: Explicit representation of subgrid heterogeneity in a GCM land-surface scheme, J. Hydrometeorology, 4, 530-543, 2003.

Friend, A. D., Lucht,W., Rademacher, T. T., Keribin, R. M., Betts, R., Cadule. P., Ciais, P., Clark, D. B., Dankers, R., Falloon, P.D., Ito, A., Kahana, R., Kleidon, A., Lomas, M. R., Nishina, K., Ostberg, S., Pavlick, R., Peylin, P., Schaphoff, S., Vuichard, N., Warszawski, L., Wiltshire, A., and Woodward, F. I.: Carbon residence time dominates uncertainty in terrestrial vegetation responses to future climate and atmospheric $\mathrm{CO}_{2}$, Proc. Natl. Ac. Sci. 111, 3280-3285, 2014

Gedney, N., Cox, P. M., and Huntingford, C.: Climate feedback from wetland methane emissions, Geophys. Res. Lett., 31, L20503, doi:10.1029/2004GL020919, 2004.

Goetz, S. J., Mack, M. C., Gurney, K. R., Randerson, J. T., and Houghton, R. A.: Ecosystem responses to recent climate change and fire disturbance at northern high latitudes: observations and model results contrasting northern Eurasia and North America, Environ. Res. Lett., 2, 045031, doi:10.1088/17489326/2/4/045031, 2007

Golding, N. and Betts, R.: Fire risk in Amazonia due to climate change in the HadCM3 climate model: Potential interactions with deforestation, Global Biogeochem. Cy., 22, GB4007, doi:10.1029/2007GB003166, 2008.

Gonzalez, P., Neilson, R. P., Lenihan, J. M., and Drapek, R. J.: Global patterns in the vulnerability of ecosystems to vegetation shifts due to climate change, Glob. Ecol. Biogeogr., 19, 755-768, 2010.

Good, P., Jones, C., Lowe, J., Betts, R., and Gedney, N.: Comparing tropical forest projections from two generations of Hadley Centre Earth System models, HadGEM2-ES and HadCM3LC, J. Climate, 26, 495-511, 2013.

Gosling, S. N. and Arnell, N. W.: Simulating current global river runoff with a global hydrological model: model revisions, validation, and sensitivity analysis, Hydrol. Proc., 25, 1129-1145, 2011. 
Heubes, J., Kühn, I., König, K., Wittig, R., Zizka, G., and Hahn, K.: Modelling biome shifts and tree cover change for 2050 in West Africa, J. Biogeogr., 38, 2248-2258, 2011.

Hickler, T., Vohland, K., Feehan, J., Miller, P. A., Smith, B., Costa, L., Giesecke, T., Fronzek, S., Carter, T. R., Cramer, W., Kühn, I., and Sykes, M. T. Projecting the future distribution of European potential natural vegetation zones with a generalized, tree species-based dynamic vegetation model, Global Ecol. Biogeogr., 21, 50-63, 2012.

Hirota, M., Holmgren, M., Van Nes, E. H., and Scheffer, M.: Global Resilience of Tropical Forest and Savanna to Critical Transitions, Science, 334, 232-235, 2011.

Hurtt, G. C., Chini, L. P., Frolking, S., Betts, R. A., Feddema, J., Fischer, G., Fisk, J. P., Hibbard, K., Houghton, R. A., Janetos, A., Jones, C. D., Kindermann, G., Kinoshita, T., Goldewijk, K. K., Riahi, K., Shevliakova, E., Smith, S., Stehfest, E., Thomson, A., Thornton, P., van Vuuren, D. P., and Wang, Y. P.: Harmonization of land-use scenarios for the period 1500-2100: 600 years of global gridded annual land-use transitions, wood harvest, and resulting secondary lands, Clim. Change, 109, 117-161, 2011.

IPCC: Summary for Policymakers, in: Climate Change 2013: The Physical Science Basis. Contribution of Working Group I to the Fifth Assessment Report of the Intergovernmental Panel on Climate Change, edited by: Stocker, T. F., Qin, D., Plattner, G.-K., Tignor, M., Allen, S. K., Boschung, J., Nauels, A., Xia, Y., Bex, V., and Midgley, P. M., Cambridge University Press, Cambridge, United Kingdom and New York, NY, USA, 3-29, 2013.

IPCC, 2014: Summary for policymakers, in: Climate Change 2014: Impacts, Adaptation, and Vulnerability, Part A: Global and Sectoral Aspects. Contribution of Working Group II to the Fifth Assessment Report of the Intergovernmental Panel on Climate Change, edited by: Field, C. B., Barros, V. R., Dokken, D. J., Mach, K. J., Mastrandrea, M. D., Bilir, T. E., Chatterjee, M., Ebi, K. L., Estrada, Y. O., Genova, R. C., Girma, B., Kissel, E. S., Levy, A. N., MacCracken, S., Mastrandrea, P. R., and White, L. L., Cambridge University Press, Cambridge, United Kingdom and New York, NY, USA, 1-32, 2014.

Jones, C., Lowe J., Liddicoat, S., and Betts, R.: Committed terrestrial ecosystem changes due to climate change, Nat. Geosci., 2, 484-487, 2009.

Jones, C. D., Hughes, J. K., Bellouin, N., Hardiman, S. C., Jones, G. S., Knight, J., Liddicoat, S., O’Connor, F. M., Andres, R. J., Bell, C., Boo, K.-O., Bozzo, A., Butchart, N., Cadule, P., Corbin, K. D., Doutriaux-Boucher, M., Friedlingstein, P., Gornall, J., Gray, L., Halloran, P. R., Hurtt, G., Ingram, W., Lamarque, J.-F., Law, R. M., Meinshausen, M., Osprey, S., Palin, E. J., Parsons Chini, L., Raddatz, T., Sanderson, M., Sellar, A. A., Schurer, A., Valdes, P., Wood, N., Woodward, S., Yoshioka, M., and Zerroukat, M.: The HadGEM2-ES implementation of CMIP5 centennial simulations, Geosci. Model Dev., 4, 543-570, 2011.

Klein Goldewijk, K. and van Drecht, G.: HYDE 3: Current and historical population and land cover, MNP (2006), edited by: Bouwman, A. F., Kram, T., and Klein Goldewijk, K., Integrated modelling of global environmental change. An overview of IMAGE 2.4. Netherlands Environmental Assessment Agency (MNP), Bilthoven, the Netherlands, 2006.

Kloster, S., Mahowald, N. M., Randerson, J. T., and Lawrence, P. J.: The impacts of climate, land use, and demography on fires during the 21st century simulated by CLM-CN, Biogeosciences, 9, 509-525, doi:10.5194/bg-9-509-2012, 2012.

Lapola, D. M., Oyama, M. D., and Nobre, C. A.: Exploring the range of climate biome projections for tropical South America: The role of $\mathrm{CO}_{2}$ fertilization and seasonality, Global Biogeochem. Cy., 23, GB3003, doi:10.1029/2008GB003357, 2009.

Lawrence, D. M., Oleson, K. W., Flanner, M. G., Fletcher, C. G., Lawrence, P. J., Levis, S., Swenson, S. C., and Bonan, G. B.: The CCSM4 land simulation, 1850-2005: Assessment of surface climate and new capabilities, J. Climate, 25, 2240-2260, 2012.

Lawrence, P. J., Feddema, J. J, Bonan, B. B., Meehl, G. A., O’Neill, B. C., Levis, S., Lawrence, D. M., Oleson, K. W., Kluzek, E., Lindsay, K., and Thornton, P. E.: Simulating the biogeochemical and biogeophysical impacts of transient land cover change and wood harvest in the Community Climate System Model (CCSM4) from 1850 to 2100, J. Climate, 25, 3071-3095, 2012.

Levis, S., Foley, J. A., and Pollard, D.: Large-scale vegetation feedbacks on a doubled $\mathrm{CO}_{2}$ climate, J. Climate, 13, 1313-1325, 2000.

Li, C., Flannigan, M. D., and Corns, I. G. W.: Influence of potential climate change on forest landscape dynamics of west central Alberta, Can. J. Forest Res., 30, 1905-1912, 2000.

Malhi, Y., Roberts, J. T., Betts, R. A., Killeen, T. J., Li, W., and Nobre, C. A.: Climate Change, Deforestation, and the Fate of the Amazon, Science, 319, 169-172, 2008.

Martin, G. M., Bellouin, N., Collins, W. J., Culverwell, I. D., Halloran, P. R., Hardiman, S. C., Hinton, T. J., Jones, C. D., McDonald, R. E., McLaren, A. J., O’Connor, F. M., Roberts, M. J., Rodriguez, J. M., Woodward, S., Best, M. J., Brooks, M. E., Brown, A. R., Butchart, N., Dearden, C., Derbyshire, S. H., Dharssi, I., Doutriaux-Boucher, M., Edwards, J. M., Falloon, P. D., Gedney, N., Gray, L. J., Hewitt, H. T., Hobson, M., Huddleston, M. R., Hughes, J., Ineson, S., Ingram, W. J., James, P. M., Johns, T. C., Johnson, C. E., Jones, A., Jones, C. P., Joshi, M. M., Keen, A. B., Liddicoat, S., Lock, A. P., Maidens, A. V., Manners, J. C., Milton, S. F., Rae, J. G. L., Ridley, J. K., Sellar, A., Senior, C. A., Totterdell, I. J., Verhoef, A., Vidale, P. L., and Wiltshire, A.:The Had GEM2 family of Met Office Unified Model climate configurations, Geosci. Model Dev., 4, 723-757, doi:10.5194/gmd-4723-2011, 2011.

Marquis, K., Averyt, B., Tignor, M., and Miller, H. L.: Cambridge University Press, Cambridge, United Kingdom and New York, NY, USA, 2014.

Matthews, H. D., Weaver, A. J., Meissner, K. J., Gillett, N. P., and Eby, M.: Natural and anthropogenic climate change: incorporating historical land cover change, vegetation dynamics and the global carbon cycle, Clim. Dynam., 22, 461-479, 2004.

Meehl, G. A., Stocker, T. F., Collins, W. D., Friedlingstein, P., Gaye, A. T., Gregory, J. M., Kitoh, A., Knutti, R., Murphy, J. M., Noda, A., Raper, S. C. B., Watterson, I. G., Weaver, A. J., and Zhao, Z.-C.: Global Climate Projections, in: Climate Change 2007: The Physical Science Basis, Contribution of Working Group I to the Fourth Assessment Report of the Intergovernmental Panel on Climate Change, edited by: Solomon, S., Qin, D., Manning, M., Chen, Z., Marquis, M., Averyt, K. B., Tignor, M., and Miller, H. L., Cambridge University Press, Cambridge, United Kingdom and New York, NY, USA.

Mercado, L. M., Bellouin, N., Sitch, S., Boucher, O., Huntingford, C., Wild, M., and Cox, P. M.: Impact of changes in diffuse radi- 
ation on the global land carbon sink, Nature, 458, 1014-U1087, 2009.

Moritz, M. A., Parisien, M. A., Batllori, E., Krawchuk, M. A., Van Dorn, J., Ganz, D. J., and Hayhoe, K.: Climate change and disruptions to global fire activity, Ecosphere, 3, 49, doi:10.1890/ES11-003451, 2012.

Moss, R. H., Edmonds, J. A., Hibbard, K. A., Manning, M. R., Rose, S. K., van Vuuren, D. P., Carter, T. R., Emori, S., Kainuma, M., Kram, T., Meehl, G. A., Mitchell, J. F. B., Nakićenović, N., Riahi, K., Smith, S. J., Stouffer, R. J., Thomson, A. M., Weyant, J. P., and Wilbanks, T. J.: The next generation of scenarios for climate change research and assessment, Nature, 463, 747-756, 2010.

Nakićenović, N., Alcamo, J., Davis, G., de Vries, B., Fenhann, J., Gaffin, S., Gregory, K., Grübler, A., Jung, T. Y., Kram, T., La Rovere, E. L., Michaelis, L., Mori, S., Morita, T., Pepper, W., Pitcher, H., Price, L., Riahi, K., Roehrl, A., Rogner, H.-H., Sankovski, A., Schlesinger, M., Shukla, P., Smith, S., Swart, R., van Rooijen, S., Nadejda, V., and Dadi, Z.: IPCC Special report on emissions scenarios. Cambridge University Press, Cambridge, United Kingdom, and New York, NY, 2000.

Nohara, D., Kitoh, A., Hosaka, M., and Oki, T.: Impact of Climate Change on River Discharge Projected by Multimodel Ensemble, J. Hydrometeor., 7, 1076-1089, 2006.

Oki, T. and Sud, Y. C.: Design of Total Runoff Integrating Pathways (TRIP) - A global river channel network, Earth Interact., 2, 1-37, 1998.

Rosenzweig, C., Karoly, D., Vicarelli, M., Neofotis, P., Wu, Q., Casassa, G., Menzel, A., Root, T.L., Estrella, N., Seguin, B., Tryjanowski, P., Liu, C., Rawlins, S., and Imeson, A.: Attributing physical and biological impacts to anthropogenic climate change, Nature, 453, 353-357, 2008.
Scheiter, S. and Higgins, S. I.: Impacts of climate change on the vegetation of Africa: an adaptive dynamic vegetation modelling approach, Glob. Change Bio., 15, 2224-2246, 2009.

Schewe, J., Heinke, J., Gerten, D., Haddeland, I., Clark, D., Dankers, R., Eisner, S., Fekete, B., Gosling, S., Kim, H., Liu, X., Masaki, Y., Portmann, F. T., Satoh, Y., Stacke, T., Tang, Q., Wada, Y., Wisser, D., Albrecht, T., Frieler, K., Piontek, F., and Warszawski, L.: How climate change will exacerbate global water scarcity, Proc. Natl. Acad. Sci., submitted, 2014.

Scholze, M., Knorr, W., Arnell, N. W., and Prentice, I. C.: A climate-change risk analysis for world ecosystems, Proc. Natl. Acad. Sci., 103, 13116-13120, 2006.

Shuman, J. K., Shugart, H. H., and O'Halloran, T. L.: Sensitivity of Siberian larch forests to climate change, Glob. Change Biol., 17, 2370-2384, 2011

Sitch, S., Huntingford, C., Gedney, N., Levy, P. E., Lomas, M., Piao, S. L., Betts, R., Ciais, P., Cox, P., Friedlingstein, P., Jones, C. D., Prentice, I. C., and Woodward, F. I.: Evaluation of the terrestrial carbon cycle, future plant geography and climate-carbon cycle feedbacks using five Dynamic Global Vegetation Models (DGVMs), Glob. Change Biol., 14, 2015-2039, 2008.

Taylor, K. E., Stouffer, R. J., and Meehl, G. A.: An Overview of CMIP5 and the Experiment Design, Bull. Amer. Meteor. Soc., 93, 485-498, 2012.

Weiser, M. D., Enquist, B. J., Boyle, B., Killeen, T. J., Jørgensen, P. M., Fonseca, G., Jennings, M. D., Kerkhoff, A. J., Lacher Jr., T. E., Monteagudo, A., Vargas, M. P. N., Phillips, O. L., Swenson, N. G., and Martínez, R. V.: Latitudinal patterns of range size and species richness of New World woody plants, Glob. Ecol. Biogeogr., 16, 679-688, 2007.

Zelazowski, P., Malhi, Y., Huntingford, C., Sitch, S., and Fisher, J. B.: Changes in the potential distribution of humid tropical forests on a warmer planet, Philosoph. Trans. Roy. Soc. A, 369, 137160, 2011. 